\title{
Decision Analysis System for Selection of Appropriate Decontamination Technologies
}

\author{
Topical Report \\ January 1998
}

\author{
By: \\ M. A. Ebadian; Joseph F. Boudreaux \\ S. Chinta; S. H. Zanakis
}

Work Performed Under Contract No.: DE-FG21-95EW55094

For

U.S. Department of Energy

Office of Fossil Energy

Federal Energy Technology Center

P.O. Box 880

Morgantown, West Virginia 26507-0880
RECEIVED

OCT 261998

Q.STI

By

Florida International University

Hemispheric Center for Environmental Technology (HCET)

Center for Engineering \& Applied Sciences

10555 West Flagler Street

EAS-2100

Miami, Florida 33174 


\section{Disclaimer}

This report was prepared as an account of work sponsored by an agency of the United States Government. Neither the United States Government nor any agency thereof, nor any of their employees, makes any warranty, express or implied, or assumes any legal liability or responsibility for the accuracy, completeness, or usefulness of any information, apparatus, product, or process disclosed, or represents that its use would not infringe privately owed rights. Reference herein to any specific commercial product, process, or service by trade name, trademark, manufacturer, or otherwise does not necessarily constitute or imply its endorsement, recommendation, or favoring by the United States Government or any agency thereof. The views and opinions of authors expressed herein do not necessarily state or reflect those of the United States Government or any agency thereof. 


\section{DISCLAIMER}

Portions of this document may be illegible in electronic image products. Images are produced from the best available original document. 
This report is based on work supported by the U.S. Department of Energy, Office of Environmental Management, Office of Science and Technology's Deactivation and Decommissioning Focus Area, Federal Energy Technology Center. The Principal Investigator, FIU Collaborators, and students at Florida International University would like to thank Dr. Paul Hart and Steve Bossart for providing us the opportunity to work on this project. 


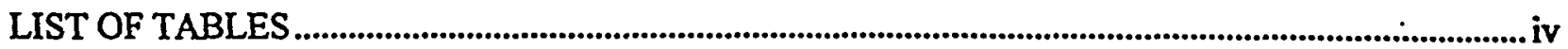

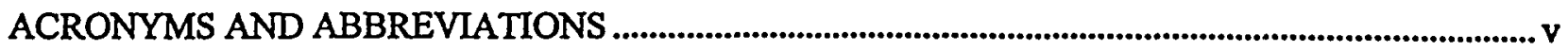

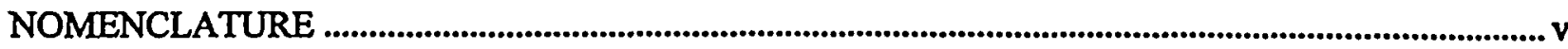

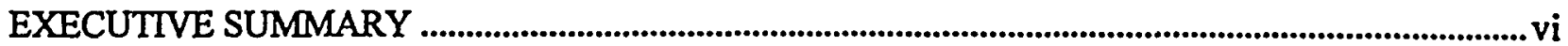

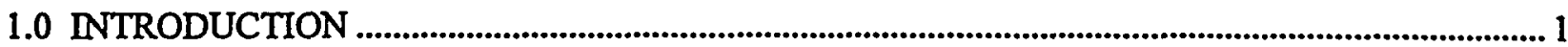

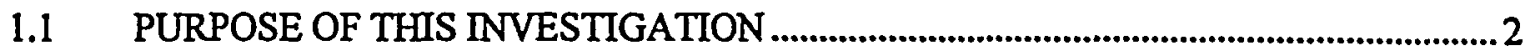

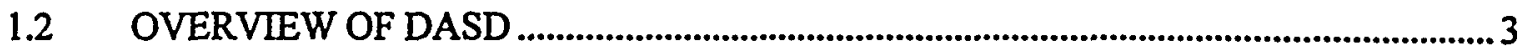

1.2.1 Multimedia Information System for Decontamination...........................................3

1.2.2 Decision Analysis System for Decontamination ..................................................... 4

1.2.3 Multi-Criteria Decision Analysis ........................................................................ 4

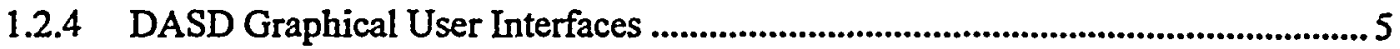

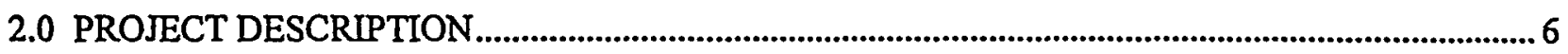

3.0 ACCOMPLISHMENTS DURING FY97

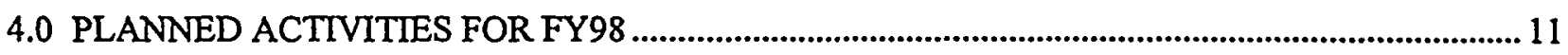

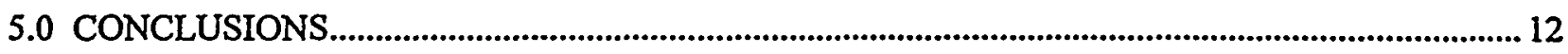

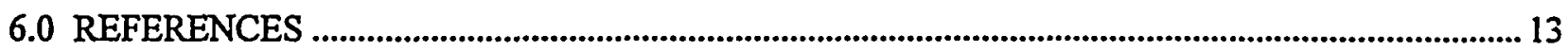

APPENDIX A. Literature Survey of Decision Models

APPENDIX B. DASD Survey Questionnaire

APPENDIX C. Data and Field Definitions

APPENDIX D. DASD Graphical User Interface (GUI)

APPENDIX E. Formulas Used for Calculating Costs 


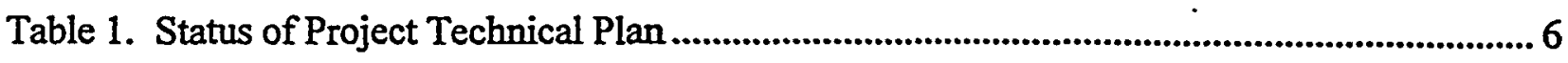

Table 2. Responses to DASD Survey .....................................................................................8 8

Table 3. Completion Schedule for Release of DASD.............................................................. 11 


\section{ACRONYMS AND ABBREVIATIONS}

D\&D Decontamination and Decommissioning

DASD Decision Analysis System for Decontamination

DOE U.S. Department of Energy

DOE-EM U.S. Department of Energy - Environmental Management

DOE-OST U.S. Department of Energy - Office of Science and Technology

FEMP

Fernald Environmental Management Project

FERMCO Fernald Environmental Restoration Management Corporation

FIU Florida International University

FIU-HCET Florida International University-Hemispheric Center for Environmental Technology

FY96 fiscal year 1996

FY97 fiscal year 1997

GUI graphical user interface

HCET Hemispheric Center for Environmental Technology

INEL Idaho National Engineering Laboratory

IUOE International Union of Operating Engineers

MISD Management Information System for Decontamination

MODM multi-objective decision making

ORNL Oak Ridge National Laboratory

PC $\quad$ personal computer

RAPIC Remedial Action Program Information Center

SAT screening of alternative technologies

$\mathrm{ft} \quad$ foot

$\mathrm{ft}^{2} \quad$ Square feet 


\section{Background}

The end of the Cold War and the decision to reduce the size of the United States' weapons production complex have created a need for the U.S. Department of Energy (DOE) to deactivate and decommission a large number of aging surplus facilities. Within the DOE Complex alone, there are some 7,000 buildings that require decontamination and decommissioning (D\&D), and material disposition. These buildings present an abundance of challenges for $D \& D$ project managers who daily must decide on the safest, most effective and cost efficient means of achieving their remediation goals. In recent years, increasing demand for remediation technologies has fueled rapid growth in the D\&D industry and attracted numerous enterprising developers and manufacturers of D\&D technologies. The result is that D\&D project managers are now faced with the task of selecting from amongst the many commercially available and innovative technologies, the most appropriate technology, or combination of technologies, that will address their specific D\&D needs.

\section{Current Means of Selecting Appropriate D\&D Technologies}

Until now, the technology selection process relied upon the D\&D manager pouring over a number of factors, criteria, and data on available technologies then trying to identify the most appropriate solution. Each candidate technology had to be assessed, taking into consideration factors such as the type, scale, and geometry of surfaces to be decontaminated; production rates; primary and secondary waste management; airborne contamination; health and safety; personal protective equipment (PPE); technology effectiveness; and cost. In addition, the pros and cons of the various methods of decontamination (e.g., mechanical, chemical, or thermal) and classes of technologies (e.g., grinding, milling, or blasting) had to be weighed. Although basic data on technologies are available from simple computerized databases (such as spreadsheets), for the most part, the process of distilling all the information and identifying the top candidates remained essentially a manual operation. The selection process can be overwhelming, time consuming, and error prone. Often, managers resort to word-of-mouth referrals; however, due to the uniqueness and idiosyncrasies of each project, without a systematic approach to technology selection, the outcome could be less than desirable and very costly.

\section{DASD-A New Generation of Computer-Assisted D\&D Decision Support}

At the Hemispheric Center for Environmental Technology at Florida International University (FIU-HCET), work is progressing toward the development of a revolutionary computerized Decision Analysis System for Decontamination (DASD). DASD is a powerful analytical tool that allows D\&D project managers to define their site-specific decontamination needs and then searches a comprehensive database of proven D\&D technologies to identify the most suitable solutions for a given project. 


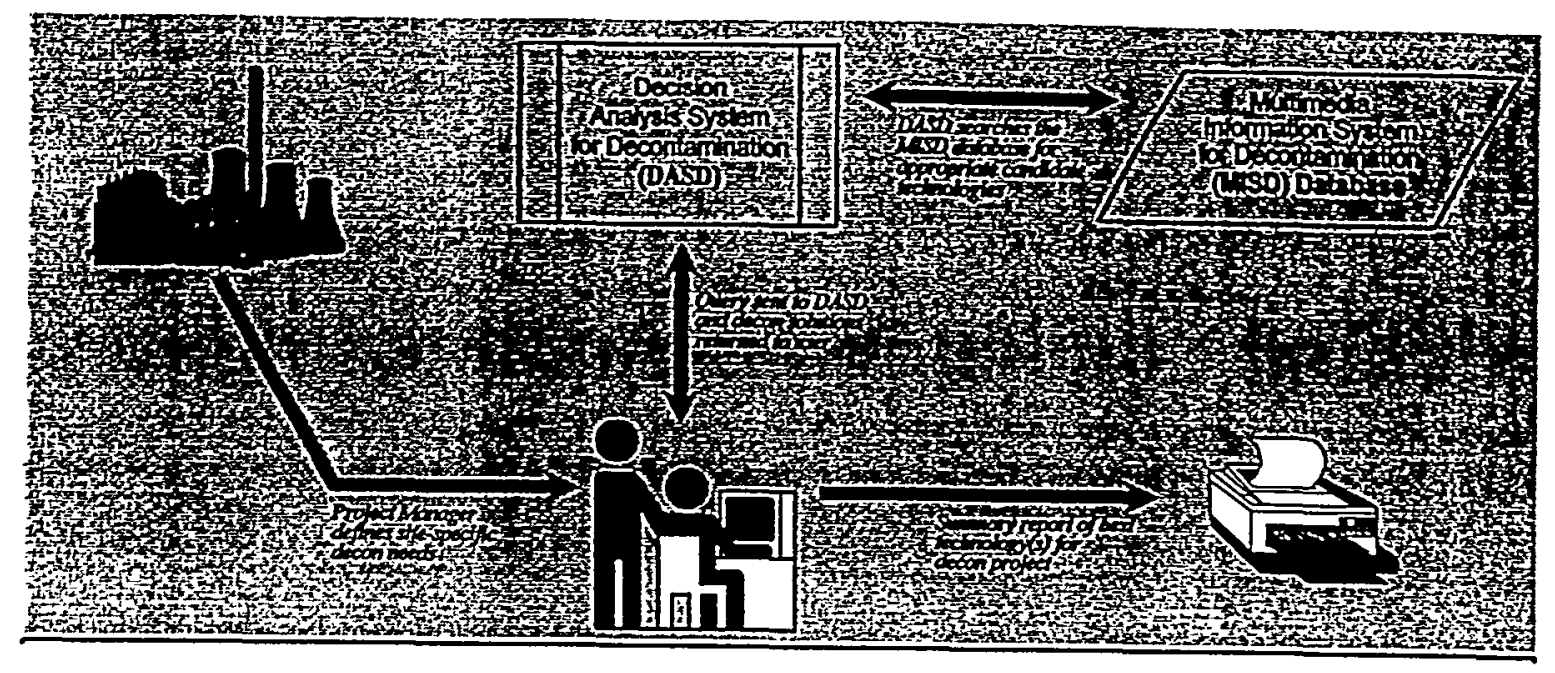

Key components of the DASD.

\section{Advantages of Using DASD}

DASD will radically reduce the time, effort, and uncertainty previously associated with selecting technologies for decontamination projects. Using DASD, D\&D project managers will be able to do the following:

- enumerate the scope and scale of their decontamination projects, and identify constraints such as budget and waste handling capacity

- assess the specific needs of their decontamination projects

- tap into up-to-date, reliable information about cutting-edge D\&D technologies that are either commercially available or in the process of being developed

- screen alternative technologies to identify leading candidates that are suitable for their projects"

- systematically score and rank candidate technologies based on the criticality of project- and technology-specific factors, as well as constraints such as time and budget

- obtain a comprehensive evaluation report on selected technologies for final review and decision

The system is designed to be very user friendly, and context-sensitive help is readily available to guide the user through every step of the process. Users do not have to be computer experts to operate the system; however, familiarity with D\&D project management terminology is necessary. 

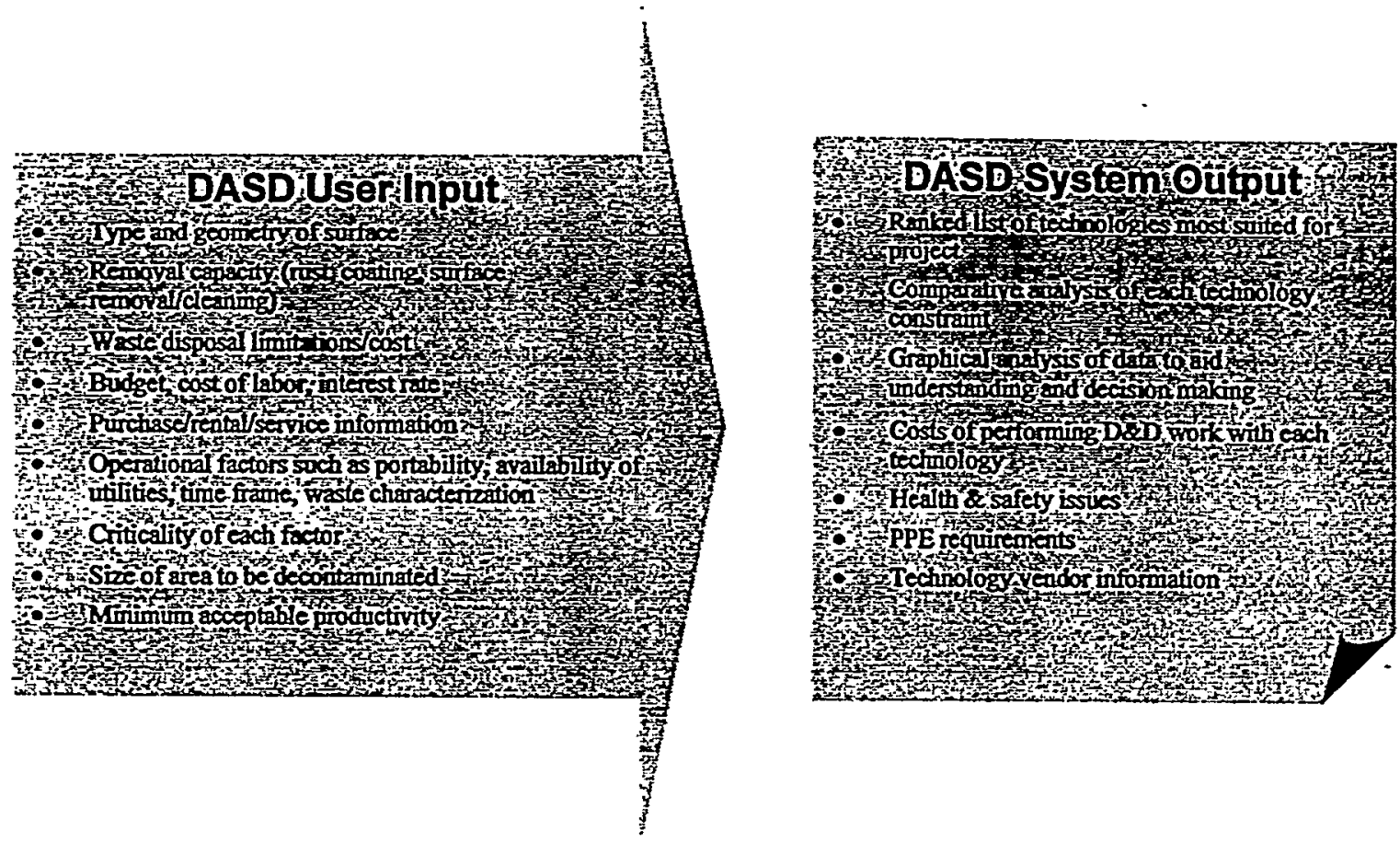

The D\&D manager inputs basic site-specific information into DASD and receives detailed comparative information on the most site-appropriate technologies.

\section{FIU-HCET-The Leading Repository of Reliable D\&D Technology Information}

The most critical feature of any decision analysis system is the comprehensiveness, accuracy, and reliability of the information it provides. Since its inception in 1995, FIU-HCET has amassed a wealth of-objective and dependable comparative D\&D technology evaluation data. In fact, FIU-HCET has performed some 35 demonstrations and assessments of innovative decontamination technologies and has participated in three large-scale technology demonstration projects at actual DOE nuclear production and research facilities. Working with the DOE and the International Union of Operating Engineers (IUOE), FIU-HCET is currently in the process of codifying technology assessment data for input into a resourceful Multimedia Information System for Decontamination (MISD), which forms the information platform of DASD. These accomplishments uniquely qualify FIU-HCET as the preeminent repository of scientifically sound decontamination technology performance data. Of particular relevance is the fact that FIU-HCET's data were collected under operating conditions that, within practical limitations, are realistic and simulate the conditions normally found at $D \& D$ project sites.

\section{Release of DASD}

The prototype release of DASD is scheduled for rollout and acceptance testing in early 1998. In this release, the task objectives will cover only the decontamination of concrete surfaces. Gradually, this will be expanded to include all basic building construction components such as 
coating and concrete surface removal from floors, walls, and ceilings, and coating and rust removal from structural steel and pipes. This information base is expected to grow rapidly as more and more technologies are scientifically evaluated and as users of the system begin to pool their information and experiences with new and innovative technologies.

This report provides an overview of the tasks involved in the development of DASD and an account of the activities completed during fiscal year 1997 (FY97). It also provides a project completion schedule and describes the activities planned for fiscal year 1998 (FY98). 


\subsection{INTRODUCTION}

Within the DOE's nuclear complex, there are approximately 7,000 radioactively contaminated buildings that require deactivation. Of these, some 1,200 buildings require decommissioning that will involve dismantlement, decontamination, and safe disposal of an estimated 550,000 metric tons of metal and 23 million cubic meters of concrete contained in the floors, walls, ceilings, and support structures of these buildings.

The principal objective of decommissioning is to permit unrestricted use of facilities or otherwise minimize risks to personnel and the environment. To this end, decommissioning plans affected by the DOE must take into account the following major concerns:

- minimizing health and safety risks to personnel and the environment

- minimizing contaminated waste volumes and airborne contamination

- maximizing the amount of recyclable materials salvaged from dismantled buildings

- remaining within budget and time constraints

These concerns pose formidable challenges for $D \& D$ project managers and are the driving force behind all decisions made when formulating D\&D plans. At DOE remediation sites, the difficulty of decision-making is further compounded by the multiplicity of site-and projectspecific factors (such as surface characteristics and geometry and contaminant types and levels) that must be considered. Undoubtedly, the single most critical decision that is affected by the above concerns and factors is the selection of the most appropriate D\&D technologies for safely, effectively, and efficiently redressing the unique set of problems and objectives associated with each remediation project.

At present, the process for selecting D\&D technologies for remediation projects is, for the most part, a manual exercise. Project managers must research, assess, compare, and evaluate copious volumes of technology performance literature and data to identify candidate technologies for their projects. In recent years, this research has been facilitated by the introduction of Preferred Alternative Matrices (PAMs). PAMs are the result of an initiative by the DOE's Office of Environmental Restoration (EM-40) to provide their field personnel with a tool for selecting "the right $[D \& D]$ technology, at the right time, at the right site."1 However, the process remains essentially a manual one. It is time consuming and costly; it does not consider all pertinent criteria, ignores user assessment of differences in criteria importance, and is sometimes based on inconsistent, incomplete, or inaccurate evaluations of technologies. Furthermore, while current selection methods go a long way in aiding in technology research, they do not provide managers with realistic "what-if" scenarios of what to expect if a particular technology were applied to their specific project and site. Before making decisions, project managers must perform elaborate computations based on their respective site- and project-specific parameters to determine the appropriateness and feasibility of using each candidate technology. This information is needed to support decisions, must be compiled manually, and typically includes the following information:

\footnotetext{
${ }^{1}$ DOE-EM web site http://www.em.doe.gov/define/pams.html
} 
- proven effectiveness of a technology to perform a task

- production rates

- cost of equipment

- cost of labor

- volume of primary and secondary waste generated and costs for disposal

- amount and cost of required PPE

- total cost for performing D\&D work

Current means of technology selection do not systematically provide this crucial information that is necessary for making decisions.

This report describes the progress achieved at FIU-HCET in developing a microcomputer-based information and decision support system for assessing D\&D project needs and identifying appropriate decontamination technology solutions. The DASD is being designed to provide project managers with reliable comparative information on proven D\&D technologies that will address their specific needs. Project and site parameters are inputted into the system, which then searches a comprehensive database of proven DOE-certified technologies for solutions. DASD then provides a ranked listing of candidate technologies that are most likely to perform successfully on the given project, as well as detailed reports on expected results, performance, costs, concerns, and health, safety and regulatory issues, among other things.

From the outset, DASD has been developed with the needs of users in mind. To fully appreciate the needs of $D \& D$ practitioners and decision-makers, a detailed survey questionnaire was sent to D\&D experts soliciting their opinions on factors and constraints that should be considered when selecting decontamination technologies. Their responses are summarized in Appendix B and, as far as possible, have been incorporated into the design of DASD.

Research and development of DASD is sponsored by the DOE's Office of Environmental Management (DOE-EM) under grant number DE-FG01-95EW55094. The project is described in FIU's Project Technical Plans numbers FIUTDD01 and FIU7DD02.

\subsection{PURPOSE OF THIS INVESTIGATION}

The principal objective for designing DASD is to support DOE-EM's endeavor to employ the most efficient and effective technologies for treating radiologically contaminated surfaces while minimizing personnel and environmental risks. DASD will provide a tool for environmental decision makers to improve the quality, consistency, and efficacy of their technology selection decisions. The system will facilitate methodical comparisons between innovative and baseline decontamination technologies and aid in identifying the most suitable technologies for performing surface decontamination at DOE envirọmental restoration sites. 


\subsection{OVERVIEW OF DASD}

Figure 1 illustrates the main processes involved in the development of DASD. The system is being developed on a Windows 95 platform and is supported by an MISD.

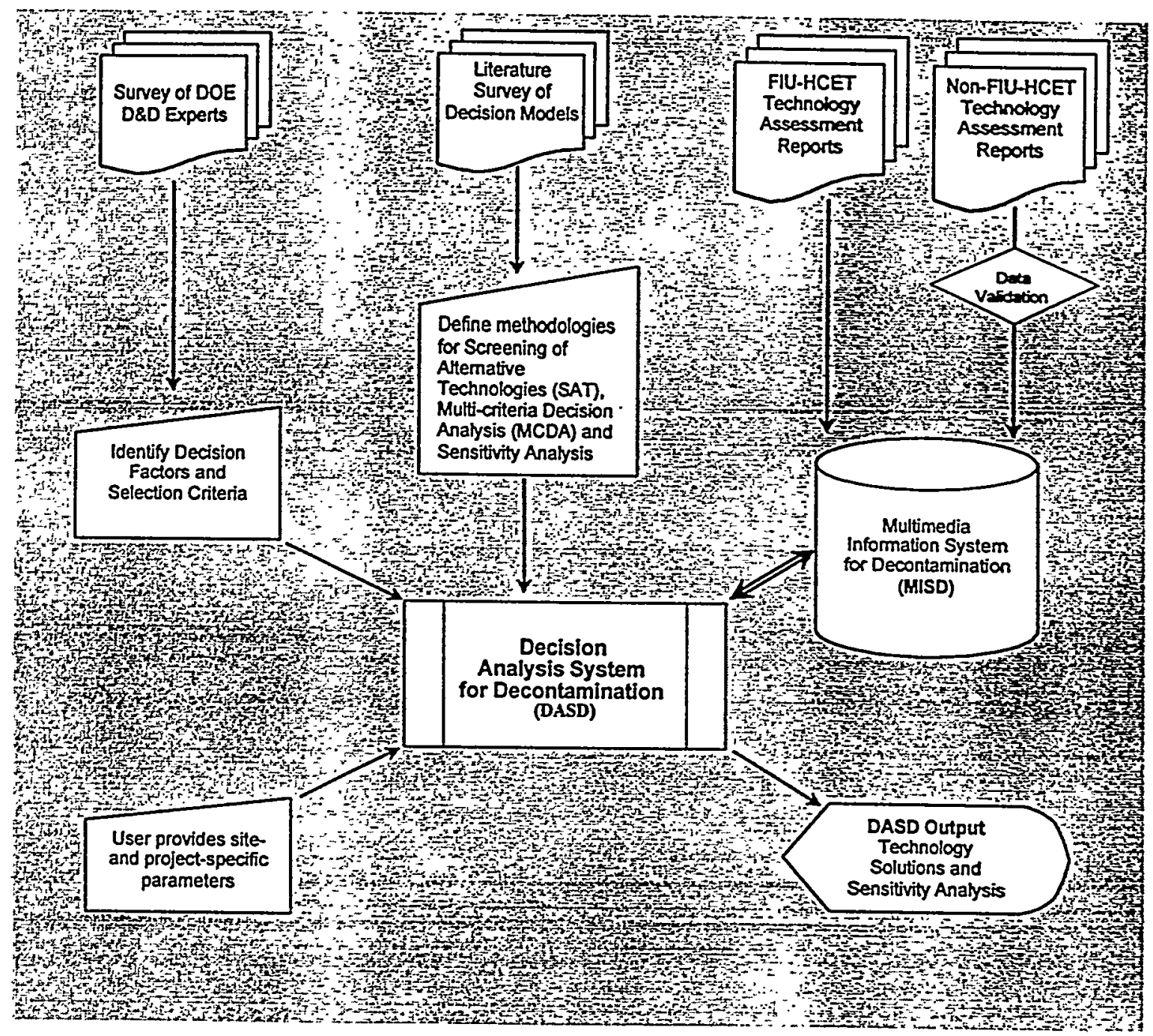

Figure 1. Process Flowchart for Decision Analysis System.

\subsubsection{Multimedia Information System for Decontamination}

A decision support system is only as useful as the quality and comprehensiveness of the information that it contains and the confidence instilled in its users. Regulatory acceptance and routine use of technology assessments by decision makers in the D\&D industry and across the DOE Complex will depend largely on the diversity, quality, objectivity, and reliability of the available information. FIU-HCET has performed some 35 demonstrations and assessments of innovative decontamination technologies alongside baseline commercial technologies to provide comparative performance data to DOE. In addition, FIU-HCET has participated in three large- 
scale technology demonstration projects at actual DOE nuclear production and research facilities. FIU-HCET is, therefore, a reliable source of scientifically sound decontamination technology performance data that were collected under realistic operating conditions. The compilation and dissemination of these data to environmental restoration decision makers in an objective and easily accessible format is of clear importance and will facilitate technology selection as well as technology transfer to industries.

To facilitate the organization and handling of the large volume of performance data that have been collected, FIU-HCET is currently developing an MISD that will provide not only a convenient interface to data queries but also technology-specific photographic and video data that will serve to further illustrate the performance of a given technology. MISD will provide an info-base framework of specific, comparable performance data that can be easily accessed by the DASD.

\subsubsection{Decision Analysis System for Decontamination}

DASD is being designed to be the main analytical and computational tool for assessing D\&D project parameters and recommending viable technology solutions. Upon entering DASD, users are prompted to input their remediation site objectives and decontamination project parameters (type, geometry, size, etc.). DASD uses this input to query the MISD database and retrieve all (five in the prototype) potential technology solutions. The user can create a new query or modify stored queries that were formulated for similar projects.

To assist users in narrowing their selection, a screening of alternative technologies (SAT) is performed first. This acts as a user-controlled filter to reduce the number of candidate technologies that are retained for further decision analysis. SAT displays a list of eligible technologies that are retrieved from the MISD database and that are capable of performing the specified decontamination tasks. It also lists operational constraints (costs, operations, functionality, and health/safety) that are associated with each candidate technology, as well as the criticality of each constraint rated on a scale from 1 (slightly desirable) to 10 (absolutely must be met by the technology). Figures D.4 and D.5 in Appendix D illustrate the results of this operation. Technologies that do not pass all critical (rated 10) constraints are eliminated. This allows the user to narrow their selection of eligible technologies even further before proceeding to more detailed evaluations. SAT provides a preliminary ranking of technologies for indicative purposes-not for final decisions. The true strength of DASD emerges at this point when users are normally faced with myriad project parameters, constraints, preferences, limitations, concerns, and technology specifications, and must somehow distill all of the information to arrive at the most appropriate technology solution.

\subsubsection{Multi-Criteria Decision Analysis}

Multi-criteria decision analysis (MCDA) is a tool that takes a user-defined multi-criteria problem set and applies it to all potential candidate solutions (in this case, the MISD database) to arrive at a numerical ranking of the most appropriate solutions. In the case of DASD, decision data associated with each technology are both qualitative and quantitative. Qualitative factors include health/safety/environmental hazards, technology operational descriptions/limitations, and technology performance characteristics (adaptability, maneuverability, media versatility, post- 
treatment surface condition, and characteristics of secondary waste). Quantitative factors include the variable costs, production rate, and waste volume, all of which translate into costs. Cost factors include capital/rental cost for decontamination and support equipment; waste disposal cost; labor and training costs for operators, technicians, health physicists and industrial hygienists; and a host of operating expenses for consumables, major equipment transportation/(de)mobilization/maintenance, and PPE. All these costs are calculated by the system based on user input. Most of this information is available in the MISD database and is fed into the decision analysis module as needed. The user will be able to enter site-specific data such as equipment transportation cost from the vendor to the site and back. MISD also provides all qualitative and descriptive information needed for those comparisons. The user can simulate what-if scenarios by overriding any information inputted or the results. In addition, the user may add a new technology to the database by providing all pertinent information so that it may be considered along with other candidates.

The core of the system is a series of user-controlled procedures for evaluating the relative importance of each decision factor. The user rates each technology factor based on their individual project circumstances and preferences, and DASD computes a score to each. Various options allow the user to rate qualitative factors, including a method for direct or pairwise comparison of factors. The user is prompted to revise the most inconsistent judgments. A help dialog box provides definitions and explanations of each factor and suggests typical operating characteristics. The final output is a rank-ordered list of qualified technologies and their overall scores. A sensitivity analysis module built into DASD identifies the critical factors that may easily alter the highest-ranked technologies. This information is important to defend judgments and focus on sensitive areas before making a final decision.

\subsubsection{DASD Graphical User Interfaces}

Graphical user interfaces (GUIs) are simply computer screens that DASD uses to request data from users, as well as to feedback information to the users. Appendix D illustrates some of the GUIs that are used by DASD. 


\subsection{PROJECT DESCRIPTION}

Table 1 summarizes the tasks that were identified for completion in FY97 in connection with the development of the computerized DASD. Also shown is the status of each task as of the end of the fiscal year on October 31, 1997.

Table 1.

Status of Project Technical Plan

\begin{tabular}{|ll|c|}
\hline \multicolumn{1}{|c|}{ Task } & Status as of October 31, 1997 \\
\hline 3.01. & Literature Survey of Decision Models & Completed \\
\hline 3.02. & $\begin{array}{l}\text { Survey D\&D Community for Input on Decision Factors and } \\
\text { Selection Criteria }\end{array}$ & Completed \\
\hline 3.03. & $\begin{array}{l}\text { Review and Approve List of Decision Factors and Selection } \\
\text { Criteria }\end{array}$ & Completed \\
\hline 3.04. & Review Available Data for Applicability to Decision Models & Completed \\
\hline 3.05. & Determine Decision Model & Completed \\
\hline 3.06. & Update Multimedia Information System & $\begin{array}{l}\text { In progress. Data for concrete surfaces } \\
\text { entered and being used for DASD } \\
\text { system prototype. }\end{array}$ \\
\hline 3.07. & Systems Analysis & Completed \\
\hline 3.08. & Design, Implement, and Integrate Software Structures & Ongoing \\
\hline 3.09. & Perform Acceptance Testing & Not completed in FY97 \\
\hline 3.10. & Develop Decision Analysis Software Manual & $\begin{array}{l}\text { Ongoing. Context-sensitive user help is } \\
\text { being built into the system. }\end{array}$ \\
\hline 3.i1. & Distribute Decision Analysis Software & Not completed in FY97. \\
\hline
\end{tabular}

These subtasks were delineated in the FY97 Project Technical Plan (PTP) and were designed to plan and manage the work activities for the year ending October 31, 1997. The goals for FY97 were to develop, test, document, and distribute the decision analysis software program. These goals were not fully achieved during FY97, primarily due to the considerable time and effort required to define and understand the project parameters, and to develop and distribute the survey questionnaire. In addition, responses to the survey were not returned in a timely manner. Despite these delays, the final deliverable for the work completed during FY97 is a prototype system of the decision analysis software that will be distributed for acceptance testing early in 1998. System enhancements and distribution of the DASD software will be completed in FY98. Section 3 of this report provides details of the status of the above tasks. 


\subsection{ACCOMPLISHMENTS DURING FY97}

Each of the tasks outlined in the FY97 PTPs "Decision Analysis Science Modeling for Application and Fielding Selection Applied to Concrete Decontamination Techniques" and "Decision Analysis Science Modeling for Application and Fielding Selection Applied to Metal Decontamination Techniques" are outlined in the following paragraphs. The tasks as found in the FY97 PTP are shown in italics. The results of these tasks follow the task statement.

\subsection{Literature Survey of Decision Models}

Task: A literature survey to gather information on decision models related to the project will be conducted. Florida International University resources, particularly, the library and faculty, DOE publications, the Internet, and national consultants are likely research sources. The goals of the task are twofold: formulate a set of potential decision models and, secondly, ascertain criteria for determining the most appropriate decision models. At the conclusion of this survey, a list of candidate decision models will be developed

Status: Completed. See Appendix A.

\subsection{Survey D\&D Community for Input on Decision Factors and Selection Criteria}

Task: Members of the D\&D community are currently making decisions regarding the application of decontamination technologies to specific sites. Decision factors and selection criteria will be identified by providing a standardized form to be completed by a group of $D \& D$ professionals. A table displaying the spectrum of decision factors and selection criteria, and their relative frequency distributions, will be formulated from the survey forms. This table will serve as a basis for determining the final list of decision factors and selection criteria.

Status: Survey questionnaires were sent to D\&D professionals throughout the DOE Complex. Of the 22 questionnaires sent out, only 7 responses were received (Table 2). Appendix $B$ is a sample of the questionnaire that was sent out. It also summarizes the responses that were received. 
Table 2.

Responses to DASD Survey

\begin{tabular}{|l|l|}
\hline Sites to which Questionnaires were sent & Responses received \\
\hline Albuquerque Operations & Yes \\
\hline Chicago Operations & Yes (Argonne National Lab) \\
\hline Fernald Environmental Management Project & Yes \\
\hline Idaho Operations & Yes \\
\hline Nevada Operations & Yes (NV-ETD) \\
\hline Oak Ridge Operations & No \\
\hline Oakland Operations & No \\
\hline Ohio Operations & Yes (Mound, Fernald) \\
\hline Richland Operations & No \\
\hline Rocky Flats Operations & Yes \\
\hline Savannah River Operations & No \\
\hline
\end{tabular}

The responses indicate that the initial factors selected by the project team were valid and complete. Additional factors that were suggested by the $D \& D$ professionals include:

- As low as reasonably achievable (ALARA) considerations as a cost element

- Costs for regulatory approval

- Risk cost associated with using an innovative technology over a baseline system

- Cost for permits, authorization basis, procedures

- Disposal cost of decontamination equipment

- Subcontracting costs

These factors were not addressed in the prototype system. As part of the acceptancetesting task, these factors will be presented to the project evaluators for a decision as to whether they should be included in the system.

\subsection{Review and Approve List of Decision Factors and Selection Criteria}

Task: Using the results of Task 3.02, a list containing the most frequently named decision factors and selection criteria will be approved. The HCET D\&D project manager and program manager, and the DOE focus area manager or his designee, will approve the list of decision factors and selection criteria.

Status: Completed. 


\subsection{Review Available Data for Applicability to Decision Models}

Task: After determining the decision factors and selection criteria, these parameters will be integrated and mapped into the parameters native to the candidate decision models. The decision model that best fits the decision factors and selection criteria will be chosen by the HCET project manager.

Status: The three main modules are User/Project Identification (Table C.1), SAT Table (Table C.3) and the Decision Analysis Model (Table D.1). The data required by the DASD were obtained from multiple sources. These sources include MISD (Table C.4), system calculations (Table C.5) and the system user (Table C.3).

\subsection{Select Decision Module}

Task: Based on the results of Task 3.04, the selected decision model will be submitted to the HCET program manager and the DOE focus area manager or his designee for approval.

Status: Completed.

\subsection{Update MISD}

Task: The MISD will be updated to reflect additional data fields that result from the determination of the final decision model. Modifications to the MISD database schema will be performed by the project manager or his assistant, and subsequent population of the MISD database will be performed by data entry personnel at HCET.

Status: This task was partially completed during FY97. Data for concrete surfaces have been entered into the system and are being used for testing the prototype. Updating will be completed in FY98.

\subsection{Systems Analysis}

Task: A software requirements and requirements specification document will be developed as part of systems analysis. The input to the requirements specification document is the requirements document which provides an abstract description of the functionality of the final software application, the implementation platform, structure of the user interface, and system operations. Using graphical models, the requirements specification document serves to clarify ambiguities, inconsistencies, and incompleteness of the requirements document. Moreover, it describes all of the objects and operations present in the system. A formal graphical model, perhaps an E-R diagram, will be adopted to illustrate system objects while finite state machines, operational models, and life cycle models are mechanisms likely to be used to model system operations. This specification document will be reviewed by a computer science faculty member specializing in the field of software engineering.

Status: Completed by FIU-HCET project team members. 


\subsection{Design, Implement, and Integrate Software Structures}

Task: The object-oriented analysis (OOA), object-oriented design (OOD), and objectoriented programming (OOP) paradigm will be used to design the software structures. The object models and interface models (OOA), created in the specification document, will be used to formulate object interaction graphs, class descriptions, and inheritance diagrams. These constructs serve as graphical descriptions of the modules and algorithms that will be written in the implementation language. Each module or class and algorithm will first be tested on paper, or logically, by the designer and, second, be tested during implementation by the programmer. As classes are put together, they will again be tested until the point that all of the classes appearing in the class description section of the design are manifested as implementation classes. Finally, the entire software application will be tested from its target user interface. Each system operation will be performed and tested methodically. Errors will be documented and submitted by the testers to the project manager for correction.

Status: Ongoing. Most modules and algorithms have already been incorporated into the completed prototype. All remaining work will be completed in FY98.

\subsection{Acceptance Testing}

Task: Acceptance testing is the process of submitting the final software application to the project initiators by the project manager and development team. A review will be conducted to ensure the software meets the stipulations software requirements document.

Status: Extensive testing is ongoing by testers at FIU-HCET. User testing will be conducted when the prototype is rolled out early in FY98.

\subsection{Develop Decision Analysis Software Manual}

Task: An online, user friendly software manual will be developed to illustrate the operation and functionality of the software and provide a help menu to facilitate the use of the software. In addition, the manual will address the type of decision models used.

Status: On-going. Context-sensitive help and guidance have been programmed directly into the software. The hardcopy manual will be completed in FY98.

\subsection{Distribute Decision Analysis Software}

Task: The decision analysis software application will be distributed to end users as determined by the program manager. A CD-ROM template may be developed for mass reproduction. The software may be implemented to execute as an applet, thereby enabling it to be distributed over the World Wide Web. If so, a Web site must be designed and implemented, and the applet must be integrated into the site. Appropriate server hardware and software must be purchased after a determination is made as to the relative frequency of use of the decision software.

Status: This task was not completed during FY97 and is planned for completion in FY98. 


\subsection{PLANNED ACTIVITIES FOR FY98}

During the first quarter of FY98, the prototype of DASD will be distributed to select D\&D professionals for testing of the system's comprehensibility, functionalities, and ease of use. Based on feedback from this test, the system will be refined, debugged, and prepared for beta distribution. Concurrently, the DASD users' manual will be compiled for distribution with the beta version. Work will continue on updating the decontamination database with data on media other than concrete. In addition, technology performance data from independent sources (other than FIU-HCET) will be investigated and, where appropriate, validated and entered into MISD. Table 3 summarizes the completion schedule for tasks to be undertaken during FY98.

Table 3.

Completion Schedule for Release of DASD

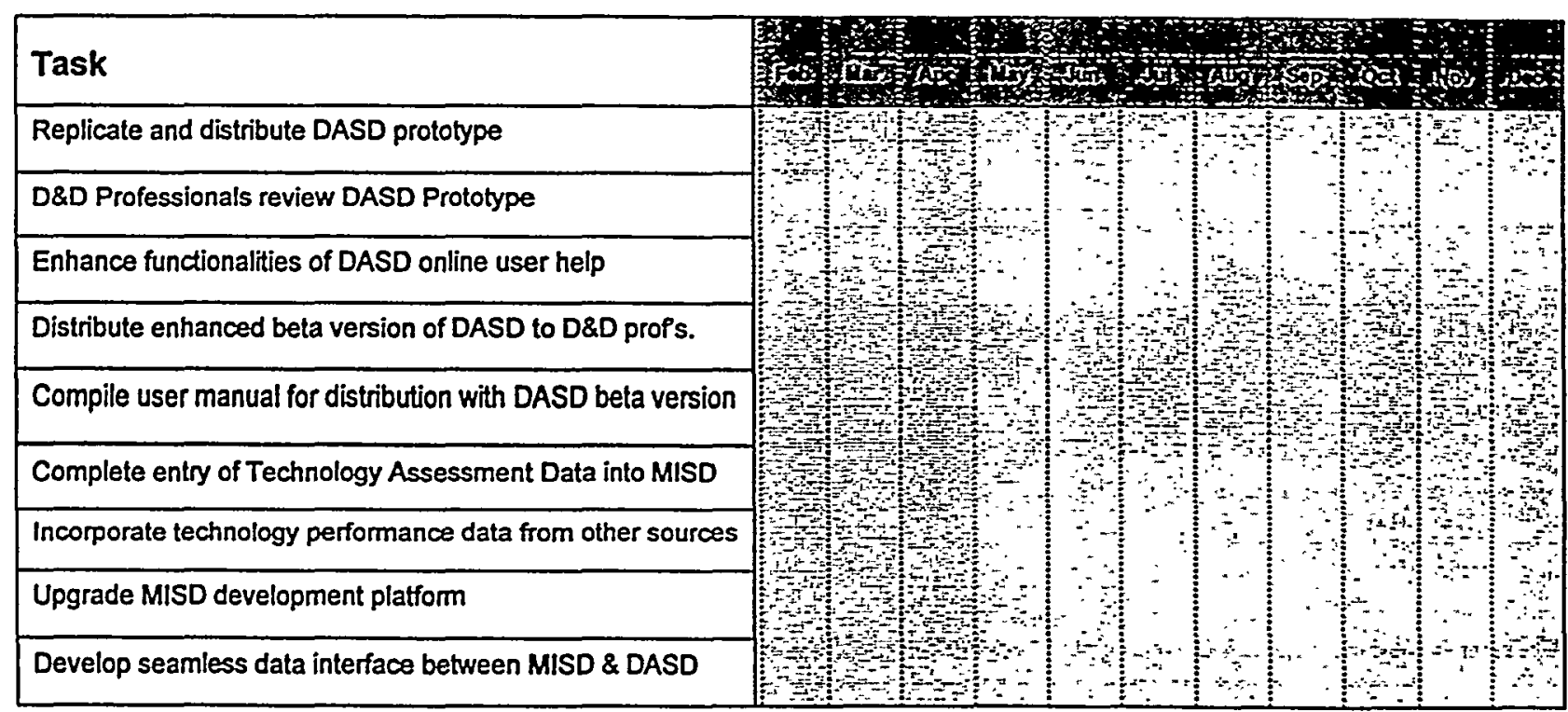


LITERATURE SURVEY OF DECISION MODELS 


\section{LITERATURE SURVEY OF DECISION MODELS *}

Selecting the most suitable decontamination method for a given problem requires the evaluation/comparison of a discrete number of alternative technologies under a multitude of data and conflicting criteria (costs and judgments on health/environmental hazards and verbal performance characteristics). This is what is known as a multicriteria decision analysis or multiattribute decision making (MADM) problem; this is a special case of multicriteria decision making (MCDM) problems that also include multi-objective optimization.

In 1957, Churchman and Ackoff \& Arnoff were among the earlier academicians to look at the MADM problem formally using a simple additive weighting (scoring) method. Over the years, different behavioral scientists, operational researchers, and decision theorists have proposed a variety of methods describing how a decision maker (DM) might arrive at a preference judgment when choosing among multiple attribute alternatives. They can be classified as: Checklist, Descriptive, Rank Ordering, Weighted Scoring, Delphi, Pair Comparisons, Utility / Preference Theory (MAUT), Outranking (French School), Fuzzy Sets and Statistical Approaches, like regression for social judgments. For a survey of MCDM methods and applications see Stewart (1992) and Zanakis et al. (1995). The latter study was a survey-based on a literature search of 306 articles published in 93 journals - of MCDM applications in the service and government sectors. The most frequent MADM approaches were pairwise comparisons (including the Analytic Hierarchy Process, or AHP) and utility/preference theory models. However, utility/preference theory models are usually complex and, thus, unattractive to many practitioners. In fact, with input from Dr. Zanakis, a group of 20 engineers and managers participating in a Florida transportation planning project selected AHP as the preferred method over four others and used it to evaluate alternative highway locations/designs involving over 100 initial criteria. For a summary of AHP and its applications, see Zahedi (1986).

Gershon and Duckstein (1983) state that the major criticism of MADM methods is that different techniques yield different results when applied to the same problem, apparently under the same assumptions and by a single user. The inconsistency in such results occurs because:

- The techniques use weights differently in their calculations

- Algorithms differ in their approach to selecting the 'best' solution

- Many algorithms attempt to scale the objectives, which affects the weights already chosen

- Some algorithms introduce additional parameters that affect which solution will be chosen.

This is compounded by the inherent differences between DMs in experimental conditions and human information processing, even under similar preferences. Other researchers have argued the opposite; namely that, given a type of problem, the solutions obtained by different MADM methods are essentially the same (Belton, 1986; Karni et al., 1990; Goicoechea et al., 1992; and Olson et al., 1995). Practitioners seem to prefer simple and transparent methods, which are unlikely to represent weight trade-offs that users are willing to make (Hobbs et al., 1992).

Many MCDA methods have been developed over the years, but more information is needed about their relative merits on similar problems. Comparative studies are either simulation or field tests. In a recent study, Zanakis et al. (1997) compared eight MADM methods on 4,800 
randomly generated test problems and concluded that alternative rankings vary across methods less in problems with few alternatives (like the decontamination problem). A literature search revealed that a limited amount of work has been done in comparing and integrating the different methods. Many authors stress the validity of the method as the key criterion for choosing it. Validity implies that the method is likely to yield choices that accurately reflect the values of the user (Hobbs et al., 1992). However, there is no absolute, objective standard of validity as preferences can be contradictory when articulated in different ways. Researchers often measure validity by checking how well a given method predicts the unaided decisions made independently of judgments used to fit the model (Schoemaker \& Waid, 1982). Decision scientists question the applicability of this criterion, particularly in complex problems that will cause users to adopt less rational heuristics and to be inconsistent. Studies in decision making have shown that the efficiency of a decision made has an inverted U-shaped relationship with the amount of information provided (Kok, 1986; and Gemunden \& Hauschildt, 1985). This is a real concern in decontamination technology assessments because of the vast amount and types of information considered.

Researchers who have attempted the task of comparing the different MADM methods have used either real-life cases or formulated a life-like problem and presented it to a selected group of (Gemunden \& Hauschildt, 1985; Belton, 1986; Roy \& Bouyssou, 1986; Buchanan \& Daellenbach, 1987; Karni, Sanchez \& Tummala, 1990; Stewart, 1992; Goicoechea et al., 1992; and Olson et al., 1995). Such field experiments are valuable tools for comparing MADM methods based on user reactions. If properly designed, they assess the impact of human information processing and judgmental decision making, beyond the nature of the methods employed. Users may compare these methods along different dimensions, such as perceived simplicity, trustworthiness, robustness, and quality.

Several authors, such as Ozernoy (1992), have outlined procedures for the selection of an appropriate MCDM method. These classifications are primarily driven by the input requirements of the method (type of information that the DM must provide and the form in which it must be provided). Very often, these classifications serve more as a tool for elimination rather than selection of the "right" method.

Our literature search through RAPIC and other library sources for multicriteria decision analysis (MCDA) applications in decontamination produced very limited results. The study by Roy and Bouyssou (1986) of nuclear power plant siting did not deal with decontamination issues. On a related topic, Henriksen (1997) applied and compared MAUT and AHP to evaluate chemical technologies for remediation of soil and groundwater contaminated with volatile organic compounds. An Information Decision Program for the clean-up of a weapons complex, U.S. Department of Energy (DOE) Office of Environmental Management, Office of Science and Technology (OST), is a management information system (MIS) for data handling without technology evaluations (Johnson et al., 1996). Preferred Alternative Matrices were developed by DOE Office of Environmental Restoration (1997), rating on a six-point scale different decontamination technologies (rows) by surface size and depth (columns). This is a good starting point for a practitioner. However, it is aggregate and static for specific problem scenarios; i.e., the user does not have details on criteria used and their importance, cannot change them according to his preferences, and cannot add new technologies or criteria. Similar benchmark 
ratings of technologies for decommissioning were recently provided in a joint DOEEnvironmental Protection Agency report (1997).

\section{Determine Appropriate Decision Model}

The literature survey and our experiences with MCDA suggest the following desirable characteristics for determining a suitable decision model:

- The model should be simple and transparent to attract user interest and understanding, yet able to handle complex evaluations.

- The model should be able to handle qualitative and quantitative information, and their tradeoffs.

- Display of measurement scales should be verbal for novices and numerical for experienced users. The former also facilitate consensus among users.

- The vast amount of information required in a decontamination task necessitates procedures for avoiding user information overload (Carmone, Kara \& Zanakis. 1997) either in comparing criteria or rating alternatives. Since this is affected more by the number of criteria, we took special care in the prototype to identify and operationalize only essential criteria. The user, however, should try to keep less than five alternatives for detailed evaluation. Reducing the number of alternatives is also important, since the final results are usually affected more by differences in alternative than criteria weights.

- Screening procedures must be employed, using constraints and desirable features, to eliminate clearly inferior alternative technologies if there are more than four candidates.

- Use two multiattribute techniques: First a robust/simple model to get results quickly and build user confidence and understanding of the system by gaining deeper insights into the problem. Second, for more experienced users, a more detailed decision model applied either directly or after the simple model to fine-tune these results.

- The final model must be able to flag irrational judgments and guide the user to revise them to his/her satisfaction. The user must have the power to override any model results.

- Graphical display of results will enhance user perceptions

- Sensitivity analysis of the results should easily identify the crucial criteria that are likely to change the top ranked technology.

The above considerations led us to the following decision model selections:

- Screening of Alternative Technologies (SAT) will be applied first. This will be a simple checklist to eliminate clearly inferior technologies that do not satisfy basic constraints. Then, a simple additive weight scoring will allow the user to screen them further, based on the extent he believes that they satisfy basic requirements.

- Those technologies that pass the SAT will be evaluated according to groups of criteria using a simple additive weight (SAW) scoring model. The user will assign criteria weights and weigh each alternative against each criterion. This decision model is usually adequate when 
comparing three to four elements simultaneously. This model will be used by a less experienced user to get problem insight and reasonable results quickly. It may also be used by a more advanced user, to reduce the computational effort involved in the next modeling process.

- A pairwise comparison decision model based on the AHP will next be used, possessing the characteristics outlined earlier. For each pair comparison on a ratio scale (numerical or verbal), the user will be asked: "How many times is A more important (better) than B?" This will be repeated to compare all pairs of criteria at a certain level of the hierarchy, as well as for each pair of alternatives under one criterion at a time. This can be time consuming for larger problems.

- AHP model refinements to expedite the procedure will include a mixed model SAW-AHP model and incomplete pair-comparison algorithms that have been found to produce statistically equivalent results with half the effort of complete AंHF (Carmone, Kara \& Zanakis, 1997).

\section{REFERENCES}

Belton, V. (1986), "A comparison of the analytic hierarchy process and a simple multi-attribute value function," European Journal of Operational Research 26, 7-21.

Buchanan, J.T., and Daellenbach, H.G. (1987), "A comparative evaluation of interactive solution methods for multiple objective decision models," European Journal of Operational Research 29, 353-359.

Carmone F., Kara A. and Zanakis, S, (1997), "A Monte Carlo Investigation of Incomplete Pairwise Comparisons in the Analytic Hierarchy Process," European Journal of Operational Research, In press.

Churchman, C.W., Ackoff, R.L., and Arnoff, E.L. (1957), Introduction to Operations Research, Wiley, New York.

Gemunden, H.G., and Hauschildt, J. (1985), "Number of alternatives and efficiency in different types of top-management decisions," European Journal of Operational Research 22, 178-190.

Gershon, M.E. \& Duckstein, L. (1983), "Multiobjective Approaches to River Basin Planning," Journal of Water Resource Planning 109, 13-28.

Goicoechea, A., Stakhiv, E.Z. \& Li, F. (1992), "Experimental Evaluation of Multiple Criteria Decision Making Models for Application to Water Resources Planning," Water Resources Bulletin 28, 89-102.

Henriksen A. (1997), "Two Decision Analysis Approaches: Choosing a Chemical Analysis Method," Remediation, Summer, 39-61. 
Hobbs, B.J., Chankong, V., Hamadeh, W., and Stakhiv E. (1992), "Does choice of multicriteria method matter? An experiment in water resource planning," Water Resources Research 28, 1767-1779.

Johnson S., Harrington M. and Marshall M., "Online Decision Support Tools for the Office of Science and Technology," Paper presented at Eco-Informa Conference, Orlando, 1996.

Karni, R., Sanchez, P., and Tummala V. (1990), “A comparative study of multiattribute decision making methodologies," Theory and Decision 29, 203-222.

Kok, M. (1986), "The interface with decision makers and some experimental results in interactive multiple objective programming methods," European Journal of Operational Research 26, 96-107.

Kok, M., and Lootsma, F.A. (1985), "Pairwise-comparison methods in multiple objective programming, with applications in a long-term energy-planning model," European Journal of Operational Research 22, 44-55.

Olson, D.L., Moshkovich, H.M., Schellenberger, R. and Mechitov, A.I. (1995), "Consistency and Accuracy in Decision Aids: Experiments with Four Multiattribute Systems," Decision Sciences 26, 723-748.

Ozernoy, V.M. (1992), "Choosing the 'best' multiple criteria decision-making method," INFOR 30, 159-171.

Roy, B. and Bouyssou, D. (1986), "Comparison of two decision-aid models applied to a nuclear power plant siting example," European Journal of Operational Research 25, 200-215.

Schoemaker, P.J. and Waid, C.C. (1982), "An experimental comparison of different approaches to determining weights in additive utility models", Management Science 28, 182-196.

Stewart, T.J. (1992), "A critical survey on the status of multiple criteria decision making theory and practice," OMEGA 20,569-586.

U.S. Department of Energy (1996), "Preferred Alternatives Matrices," Environmental Restoration Program Requirements Report, EM-40, Washington, D.C.

U.S. Department of Energy \& U.S. Environmental Protection Agency (1997), "Decommissioning Benchmarking Study," Final Report, Washington, D.C.

Zahedi, F. (1986), "The Analytic Hierarchy Process-A Survey of the Method and Its Applications," Interfaces 16, 96-108.

Zanakis, S., Mandakovic, T., Gupta, S., Sahay, S. and Hong, S. (1995), "A Review of Program Evaluation \& Fund Allocation Methods Within the Service \& Government Sectors," Socio-Economic Planning Sciences 29, 59-79.

Zanakis S., Solomon A., Wishart N. and Dublish S. (1997), "Multi-Attribute Decision Making: A Comparison of Select Methods," European Journal of Operational Research, in press. 


\section{APPENDIX B}

\section{DASD SURVEY QUESTIONNAIRE}




\section{DASD SURVEY QUESTIONNAIRE}

The following is a reproduction of the survey questionnaire that was sent to D\&D professionals soliciting their views on the decision factors and selection criteria to be incorporated into DASD.

\section{DATA CATEGORIES REVIEW}

The purpose of the Data Categories Table is to provide a definition for each data category and to determine the importance of each. The site-specific constraints data category has been omitted because constraints do not need to be rated. Reviewers were asked to assess the data categories and, based on the importance scale provided, rate the general importance of each.

\begin{tabular}{|c|c|c|c|}
\hline \multicolumn{2}{|c|}{$\begin{array}{l}\text { Table B.1. } \\
\text { Data Categories Table } \\
\text { (Text in italics are results of the survey of D\&D professionals.) }\end{array}$} & \multicolumn{2}{|c|}{$\begin{array}{ll}\text { Importance Scale } \\
1 & \text { not important } \\
2 & \text { slightly important } \\
3 & \text { moderately important } \\
4 & \text { very important } \\
5 & \text { absolutely important }\end{array}$} \\
\hline Data Category & \multicolumn{2}{|l|}{ Definition } & Rating \\
\hline Cost Data & \multicolumn{2}{|c|}{$\begin{array}{l}\text { Cost is a data category, which represents the data necessary to reveal which } \\
\text { technology is more or less costly than another for the same application in the } \\
\text { same project. Please see the cost elements table in Section I for a detailed } \\
\text { specification of the cost data. }\end{array}$} & $\begin{array}{l}12345 \\
\text { Mean: } 4.7\end{array}$ \\
\hline $\begin{array}{l}\text { Technology } \\
\text { Performance }\end{array}$ & \multicolumn{2}{|c|}{$\begin{array}{l}\text { Technology Performance is a data category, which represents the data } \\
\text { describing a decontamination technology's capability to perform } \\
\text { decontamination. In simple terms these data elements should answer the } \\
\text { questions: What can it do? What are its limitations? The data elements are: } \\
\text { adaptability to different surface profiles, characteristics of secondary waste, } \\
\text { equipment maneuverability, media versatility, production rate, and removal } \\
\text { capacity. }\end{array}$} & $\begin{array}{l}12345 \\
\text { Mean: } 4.0\end{array}$ \\
\hline Technology Design & \multicolumn{2}{|c|}{$\begin{array}{l}\text { The data in the technology design category describes a decontamination } \\
\text { technology's design efficiency. In simple terms, these data elements should } \\
\text { answer the question: How does it work? The data elements are: operating } \\
\text { details, operational and maintenance requirements, operational limitations, } \\
\text { and environmental conditions. }\end{array}$} & $\begin{array}{l}12345 \\
\text { Mean: } 3.5\end{array}$ \\
\hline
\end{tabular}

\section{SECTION I: COST DATA}

During the process of selecting a decontamination technology for a project from a group of viable alternatives, a decision-maker analyzes the cost data available for these alternatives to determine which is most cost effective for a given site. All cost elements may not have the same importance with regard to minimizing total project costs because of possible tradeoffs between cost elements due to budgetary, policy, or site-specific reasons. The purpose of this section is to a) present and define the cost elements; b) allow you to rate each cost element; c) allow you to make changes to the cost elements and d) allow you to add new cost elements. The cost items used to determine each cost element are listed in the Cost Item column. The parameters used by 
the decision analysis model to compute the cost items are listed in the Parameters column. Reviewers were requested to examine the cost elements in the table below and, using the importance scale provided, indicate the relative importance of minimizing each. Reviewers were also encouraged, where appropriate, to modify the given cost elements, or to add new ones.

\begin{tabular}{|c|c|c|c|c|}
\hline \multicolumn{3}{|c|}{$\begin{array}{c}\text { Table B.2. } \\
\text { Cost Elements } \\
\text { (Text in italics are results of the survey of D\&D professionals) }\end{array}$} & \multicolumn{2}{|c|}{$\begin{array}{ll}\text { Importance Seale } \\
1 & \text { not important } \\
2 & \text { slightly important } \\
3 & \text { moderately important } \\
4 & \text { very important } \\
5 & \text { absolutely important }\end{array}$} \\
\hline Cost Element & Cost Item & Paramet & & Rating \\
\hline \multirow{3}{*}{$\begin{array}{l}\text { Health and Safety } \\
\text { Costs }\end{array}$} & Industrial hygienist support & $\begin{array}{l}\text { Total num } \\
\text { hours requ } \\
\text { Labor rate }\end{array}$ & ygienists man & \multirow{3}{*}{$\begin{array}{l}12345 \\
\text { Mean: } 3.6\end{array}$} \\
\hline & Health physics support & $\begin{array}{l}\text { Total num } \\
\text { man hours } \\
\text { Labor rate }\end{array}$ & $\begin{array}{l}\text { ealth physicists } \\
\text { d }\end{array}$ & \\
\hline & $\begin{array}{l}\text { Total PPE (personal protective } \\
\text { equipment) }\end{array}$ & $\begin{array}{l}\text { For each t } \\
\text { Number o } \\
\text { Cost per it }\end{array}$ & $\begin{array}{l}\text { PE item: } \\
\text { equired }\end{array}$ & \\
\hline \multirow[t]{2}{*}{$\begin{array}{l}\text { Transportation } \\
\text { Costs }\end{array}$} & $\begin{array}{l}\text { (i) Transporting of capital } \\
\text { equipment to vendor from site }\end{array}$ & $\begin{array}{l}\text { Vendor LC } \\
\text { Equipmen } \\
\text { User prov }\end{array}$ & $\begin{array}{l}\text { ility } \\
\text { it estimate }\end{array}$ & \multirow[t]{2}{*}{$\begin{array}{l}12345 \\
\text { Mean: } \quad 2.6\end{array}$} \\
\hline & $\begin{array}{l}\text { (ii) Transporting of capital } \\
\text { equipment to site from vendor } \\
\text { "Transportation costs are generated } \\
\text { by providing the decision-maker } \\
\text { with vendor location and } \\
\text { equipment transportation } \\
\text { information }\end{array}$ & \multicolumn{2}{|c|}{$\begin{array}{l}\text { Vendor Location } \\
\text { Equipment portability } \\
\text { User provided cost estimate }\end{array}$} & \\
\hline
\end{tabular}




\begin{tabular}{|c|c|c|c|}
\hline $\begin{array}{l}\text { Capital Equipment } \\
\text { Costs }\end{array}$ & Case 1: Purchase & $\begin{array}{l}\text { Capital equipment cost prorated } \\
\text { based on hours to be used }\end{array}$ & $\begin{array}{l}12345 \\
\text { Mean: } 3.9\end{array}$ \\
\hline & Case 2: Rental & Capital equipment rental cost & \\
\hline $\begin{array}{l}\text { Waste Disposal } \\
\text { Costs }\end{array}$ & Waste disposal & $\begin{array}{l}\text { Total Volume of waste in } \mathrm{ft}^{3} \text { per } \mathrm{ft}^{2} \text { of } \\
\text { decontaminated surface } \\
\text { Waste disposal cost per } \mathrm{ft}^{3} \text { of waste }\end{array}$ & $\begin{array}{l}12345 \\
\text { Mean: } 4.7\end{array}$ \\
\hline Training Costs & $\begin{array}{l}\text { Case 1: Site personnel to operate } \\
\text { equipment }\end{array}$ & $\begin{array}{l}\text { Equipment technology training cost } \\
\text { per person } \\
\text { Amount of equipment operators } \\
\text { needed }\end{array}$ & $\begin{array}{l}12345 \\
\text { Mean: } 2.7\end{array}$ \\
\hline & $\begin{array}{l}\text { Case 2: Service provider to operate } \\
\text { equipment }\end{array}$ & $\begin{array}{l}\text { Site specific health physics and } \\
\text { safety training cost per person } \\
\text { Amount of equipment operators } \\
\text { needed }\end{array}$ & \\
\hline \multirow{3}{*}{ Operating Costs } & $\begin{array}{l}\text { Total consumables cost per } \mathrm{ft}^{2} \text { of } \\
\text { decontaminated surface }\end{array}$ & $\begin{array}{l}\text { For each consumable item: } \\
\text { Consumable item unit cost } \\
\text { Consumable item consumption rate } \\
\text { per } \mathrm{ft}^{2}\end{array}$ & \multirow[t]{3}{*}{$\begin{array}{l}12345 \\
\text { Mean: } 3.7\end{array}$} \\
\hline & $\begin{array}{l}\text { Total replacement parts cost per } \mathrm{f}^{2} \\
\text { of decontaminated surface }\end{array}$ & $\begin{array}{l}\text { For each replacement part: } \\
\text { - Part cost } \\
\text { - Life of the part in } \mathrm{ft}^{2}\end{array}$ & \\
\hline & $\begin{array}{l}\text { Total utility costs per } \mathrm{f}^{2} \text { of } \\
\text { decontaminated surface }\end{array}$ & $\begin{array}{l}\text { For each utility: } \\
\text { Utility cost per unit } \\
\text { Utility consumption rate per } \mathrm{ft}^{2} \text { of } \\
\text { decontaminated surface }\end{array}$ & \\
\hline Labor Costs & $\begin{array}{l}\text { Total labor cost for: operating } \\
\text { decontamination capital } \\
\text { equipment; capital equipment } \\
\text { staging; unloading capital } \\
\text { equipment from carrier; capital } \\
\text { equipment cleaning and } \\
\text { decontamination; loading capital } \\
\text { equipment onto carrier. Staging } \\
\text { refers to the transport and setup of } \\
\text { the capital equipment in the target } \\
\text { area after unloading. }\end{array}$ & $\begin{array}{l}\text { For each labor classification: } \\
\text { Total man hours } \\
\text { Labor rate }\end{array}$ & $\begin{array}{l}12345 \\
\text { Mean: } 4.0\end{array}$ \\
\hline
\end{tabular}




\begin{tabular}{|c|c|c|c|}
\hline \multirow[t]{2}{*}{$\begin{array}{l}\text { Support } \\
\text { Equipment/Tools } \\
\text { Cost }\end{array}$} & $\begin{array}{l}\text { Case 1- Rental. Total cost of: } \\
\text { support equipment/tools needed for } \\
\text { decontamination; capital } \\
\text { equipment staging and destaging; } \\
\text { loading and unloading capital } \\
\text { equipment to and from carrier; } \\
\text { capital equipment cleaning and } \\
\text { decontamination. }\end{array}$ & $\begin{array}{l}\text { For each piece of support equipment: } \\
\text { Support equipment use in hours } \\
\text { Support equipment rental rate }\end{array}$ & \multirow[t]{2}{*}{$\begin{array}{l}12345 \\
\text { Mean: } 3.3\end{array}$} \\
\hline & $\begin{array}{l}\text { Case 2-Purchase. Total cost of: } \\
\text { support equipment/tools needed for } \\
\text { decontamination, capital } \\
\text { equipment staging and destaging, } \\
\text { loading and unloading capital } \\
\text { equipment to and from carrier, } \\
\text { capital equipment cleaning and } \\
\text { decontamination. }\end{array}$ & $\begin{array}{l}\text { For each piece of support equipment: } \\
\text { Support equipment purchase cost } \\
\text { prorated based on hours to be used }\end{array}$ & \\
\hline \multicolumn{4}{|c|}{$\begin{array}{l}\text { Please insert and rate any additional cost elements that you feel should be included in the } \\
\text { Decision Analysis Model }\end{array}$} \\
\hline Compliance costs & $\begin{array}{l}\text { Necessary permits to operate } \\
\text { equipment }\end{array}$ & $R C R A, N R A, C A A$, etc. & Mean: 3 \\
\hline $\begin{array}{l}\text { Secondary waste } \\
\text { disposal cost }\end{array}$ & $\begin{array}{l}\text { Cost to treat or dispose of } \\
\text { secondary waste generated }\end{array}$ & $\begin{array}{l}\text { Total volume of secondary waste } \\
\text { generated per fit of surface cleaned. }\end{array}$ & Mean: 5 \\
\hline Life Cycle Cost & $\begin{array}{l}\text { Includes development, } \\
\text { implementation, operation, } \\
\text { secondary waste cost }\end{array}$ & & Mean: 4 \\
\hline Implementation & $\begin{array}{l}\text { Procedures, authorization basis, } \\
\text { etc. }\end{array}$ & ' & Mean: 4 \\
\hline Health and Safety & Layers of PPE & $\begin{array}{l}\text { Are multiple layers required? How } \\
\text { does this affect production? }\end{array}$ & Mean: 3 \\
\hline Capital Costs & Rental & Cost per unit processed & Mean: 5 \\
\hline Proposed Cost & Total contract cost for all work & & Mean: 5 \\
\hline $\begin{array}{l}\text { Disposal Cost of } \\
\text { Equipment }\end{array}$ & $\begin{array}{l}\text { Cost associated with disposal of } \\
\text { equipment }\end{array}$ & $\begin{array}{l}\text { Decontamination costs } \\
\text { Disposal costs }\end{array}$ & Mean: 4 \\
\hline
\end{tabular}

\section{SECTION II. TECHNOLOGY PERFORMANCE}

During the process of selecting a decontamination technology for a project from a group of viable technology alternatives, an environmental restoration decision-maker evaluates the 
decontamination performance of these technologies. Data elements for the technology performance category are presented in the table below along with a definition and importancerating column. The purpose of this table is to provide a definition for each data element and to determine the importance of each element. Reviewers were requested to examine the definition of each data element and, using the importance scale provided, indicate in the rating column the relative importance of the data to making technology performance comparisons during the technology selection process. Users were also asked to suggest and rate additional technology performance data elements that they felt should be included.

\begin{tabular}{|c|c|c|c|}
\hline $\begin{array}{r}\text { Te } \\
\text { Text in itc }\end{array}$ & $\begin{array}{l}\text { Table B.3. } \\
\text { ology Performance Data Elements } \\
\text { are results of the survey of } D \& D \text { professionals) }\end{array}$ & $\begin{array}{ll}\text { Importance Scale } \\
1 & \text { not important } \\
2 & \text { slightly import } \\
3 & \text { moderately imp } \\
4 & \text { very important } \\
5 & \text { absolutely imp }\end{array}$ & $\begin{array}{l}\text { nt } \\
\text { ortant } \\
\text { rtant . } \\
\text { Rating }\end{array}$ \\
\hline $\begin{array}{l}\text { Adaptability to } \\
\text { Different Surfaces }\end{array}$ & $\begin{array}{l}\text { Information describing the equipment's ability } \\
\text { of different types of surfaces, surface conditions }\end{array}$ & $\begin{array}{l}\text { decontamination } \\
\text { ace profiles. }\end{array}$ & $\begin{array}{l}12345 \\
\text { Mean: } 4.0\end{array}$ \\
\hline $\begin{array}{l}\text { Characteristics of } \\
\text { Secondary Waste }\end{array}$ & $\begin{array}{l}\text { A description of the physical, chemical, and radi } \\
\text { waste generated by the operation of the decontan }\end{array}$ & $\begin{array}{l}\text { ondition of the } \\
\text { technology. }\end{array}$ & $\begin{array}{l}12345 \\
\text { Mean: } 4.3\end{array}$ \\
\hline $\begin{array}{l}\text { Equipment } \\
\text { Maneuverability }\end{array}$ & $\begin{array}{l}\text { Information describing the maneuverability of de } \\
\text { during the decontamination process, including al } \\
\text { corners and edges, directions of equipment trave } \\
\text { walls, ceilings, and confined spaces. }\end{array}$ & $\begin{array}{l}\text { nation equipment } \\
\text { lecontaminate } \\
\text { lity to operate on }\end{array}$ & $\begin{array}{l}12345 \\
\text { Mean: } 4.0\end{array}$ \\
\hline Media Versatility & $\begin{array}{l}\text { Information describing whether the decontamina } \\
\text { various grades of decontamination media and if }\end{array}$ & $\begin{array}{l}\text { nology can utilize } \\
\text { is recyclable. }\end{array}$ & $\begin{array}{l}12345 \\
\text { Mean: } 3.3\end{array}$ \\
\hline $\begin{array}{l}\text { Post- } \\
\text { Decontamination } \\
\text { Surface Condition }\end{array}$ & $\begin{array}{l}\text { A brief description of the surface revealed by the } \\
\text { technology with respect to consistency, texture, } \\
\text { a smooth, even surface.) }\end{array}$ & $\begin{array}{l}\text { mination } \\
\text { (Example: leaves }\end{array}$ & $\begin{array}{l}12345 \\
\text { Mean: } 2.6\end{array}$ \\
\hline $\begin{array}{l}\text { Production Rate } \\
\left(\mathrm{ft}^{2} / \mathrm{h}\right)\end{array}$ & $\begin{array}{l}\text { The surface area successfully decontaminated } \\
\text { respect to time. }\end{array}$ & en technology with & $\begin{array}{l}12345 \\
\text { Mean: } 4.3\end{array}$ \\
\hline $\begin{array}{l}\text { Removal } \\
\text { Capability }\end{array}$ & $\begin{array}{l}\text { The depth of surface media that can be removed } \\
\text { technology. In the case of concrete, for example, } \\
\text { described in increasing increments as follows: cc } \\
\text { inch, and crack. }\end{array}$ & $\begin{array}{l}\text { n decontamination } \\
\text { capabilities are } \\
\text { inch, } 1 / 2 \text { inch, } 1\end{array}$ & $\begin{array}{l}12345 \\
\text { Mean: } 3.9 \\
\end{array}$ \\
\hline Please insert & $\begin{array}{l}\text { Ite any additional technology perfo } \\
\text { ithe Decision Analysis Model. }\end{array}$ & a cat & you fee \\
\hline & [No additional data elements suggested] & & $\begin{array}{l}12345 \\
\text { Mean: }\end{array}$ \\
\hline
\end{tabular}




\section{SECTION III. TECHNOLOGY DESIGN}

During the process of selecting a decontamination technology for a project from a group of viable technology alternatives, an environmental restoration decision-maker evaluates the design of these decontamination technologies. Technology design data elements are presented in the table below along with a definition and importance-rating column. The purpose of this table is to provide a definition for each data element and to determine the importance of each element. For each data element, please examine the definition and indicate in the rating column how important you feel this type of data is for making comparisons of decontamination technologies during the decontamination technology selection process. More than one data element can be assigned the same importance rating. Use the importance scale to quantify your judgments. Please include additional Technology Design data elements at the bottom of the table with their corresponding importance rating.

\begin{tabular}{|c|c|c|c|}
\hline \multicolumn{2}{|c|}{$\begin{array}{c}\text { Table B.4. } \\
\text { Technology Design Data Elements } \\
\text { (Text in italics are results of the survey of } D \& D \text { professionals) }\end{array}$} & \multicolumn{2}{|c|}{$\begin{array}{|ll|}\text { Importance Scale: } \\
1 & \text { not important } \\
2 & \text { slightly important } \\
3 & \text { moderately important } \\
4 & \text { very important } \\
5 & \text { absolutely important }\end{array}$} \\
\hline Data Element & \multicolumn{2}{|l|}{ Definition } & Rating \\
\hline $\begin{array}{l}\text { Environmental } \\
\text { Conditions }\end{array}$ & \multicolumn{2}{|c|}{$\begin{array}{l}\text { A description of the environment created by the operation of the } \\
\text { decontamination technology including, but not limited to, dust generation, } \\
\text { scattering of particles and media, fumes, visibility, noise, and temperature. }\end{array}$} & $\begin{array}{l}12345 \\
\text { Mean: } 4.3\end{array}$ \\
\hline $\begin{array}{l}\text { Equipment } \\
\text { Portability }\end{array}$ & \multicolumn{2}{|c|}{$\begin{array}{l}\text { The number of persons and/or equipment required to transport the } \\
\text { equipment during staging. Staging refers to the transport and setup of the } \\
\text { capital equipment in the target area after unloading. }\end{array}$} & $\begin{array}{l}12345 \\
\text { Mean: } 3.6\end{array}$ \\
\hline Operating Details & \multicolumn{2}{|c|}{$\begin{array}{l}\text { A technical description of how a given technology removes the } \\
\text { contaminant from its host. Parameters include: secondary waste system, } \\
\text { type of decontamination media, open vs. closed loop system, and } \\
\text { descriptions of unique equipment components used or required. }\end{array}$} & $\begin{array}{l}12345 \\
\text { Mean: } 3.7\end{array}$ \\
\hline $\begin{array}{l}\text { Operational } \\
\text { Limitations }\end{array}$ & \multicolumn{2}{|c|}{$\begin{array}{l}\text { Parameters that limit the operation of a technology as observed during } \\
\text { demonstration at HCET and/or as described in vendor provided literature. }\end{array}$} & $\begin{array}{l}12345 \\
\text { Mean: } 4.0\end{array}$ \\
\hline $\begin{array}{l}\text { Operational and } \\
\text { Maintenance } \\
\text { Requirements }\end{array}$ & \multicolumn{2}{|c|}{$\begin{array}{l}\text { The operational and maintenance requirements provide an account of the } \\
\text { types of operational and maintenance activities performed during the hours } \\
\text { of operation of the equipment. }\end{array}$} & $\begin{array}{l}12345 \\
\text { Mean: } 3.7\end{array}$ \\
\hline Please insert a & $\begin{array}{l}\text { any additional technology design } \\
\text { on Analysis Model. }\end{array}$ & nts that you f & hould be \\
\hline
\end{tabular}




\begin{tabular}{|l|l|l|}
\hline $\begin{array}{l}\text { Expected lifetime or } \\
\text { replacement } \\
\text { information }\end{array}$, & $\begin{array}{l}\text { Amount of decontamination work that can be done before replacing the } \\
\text { equipment. }\end{array}$ & Mean: 3 \\
\hline Simplicity & $\begin{array}{l}\text { Operations, maintenance, ergonomics as applied to a radiological } \\
\text { environment. }\end{array}$ & Mean: 4 \\
\hline Engineered safety & $\begin{array}{l}\text { Criticality prevention, engineered featured (guards, kill switches) alarms } \\
\text { radiological safety }\end{array}$ & Mean: 4 \\
\hline Durability & Length of use between repair, re-charge, refill, etc. & Mean: 3 \\
\hline
\end{tabular}

\section{SECTION IV. SITE-SPECIFIC CONSTRAINTS}

In order to effectively apply the decision analysis model, a screening process will narrow the pool of technology alternatives. Existing project-specific and site-specific constraints can nullify the viability of a given technology alternative. The purpose of this section is to gather a list of general site-specific constraints that can be used to exclude a technology from consideration for a given decontamination project. These constraints are presented in the table below as questions to which you can answer with one of three choices: always, sometimes, or never. Please examine each constraint question and check the correct answer in the applicability column. At the end of this table, you will find additional rows for inserting constraints. Please include additional constraint statements that can be used to screen technology alternatives from consideration in a decision scenario. If necessary, additional constraints can also be noted on a separate sheet and submitted with this survey.

Table B.5.

Site-Specific Constraints Table

(Arrow heads indicate the trend in the responses of $D \& D$ professionals to the survey questionnaire)

\begin{tabular}{|c|c|c|c|}
\hline \multicolumn{3}{|c|}{$\begin{array}{l}\text { Applicability } \\
\text { Always|Some- Never } \\
\text { times } \mid\end{array}$} & $\begin{array}{l}\text { Constraint Questions } \\
\text { Please indicate frequency by placing a checkmark in the appropriate column. }\end{array}$ \\
\hline \multicolumn{4}{|c|}{ Cost Constraints } \\
\hline 1 & & & $\begin{array}{l}\text { How often is the capital equipment cost a limiting constraint during the process of selecting } \\
\text { a decontamination technology? }\end{array}$ \\
\hline \multirow[t]{3}{*}{ 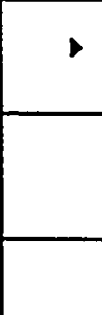 } & & & $\begin{array}{l}\text { How often is the operating cost a limiting constraint during the process of selecting a } \\
\text { decontamination technology? }\end{array}$ \\
\hline & 4 & & $\begin{array}{l}\text { How often is the labor cost a limiting constraint during the process of selecting a } \\
\text { decontamination technology? }\end{array}$ \\
\hline & 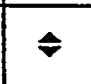 & & $\begin{array}{l}\text { How often is the support equipment cost a limiting constraint during the process of } \\
\text { selecting a decontamination technology? }\end{array}$ \\
\hline
\end{tabular}


Table B.5.

Site-Specific Constraints Table

(Arrow heads indicate the trend in the responses of $D \& D$ professionals to the survey questionnaire)

\begin{tabular}{|c|c|c|c|}
\hline \multicolumn{3}{|c|}{$\begin{array}{l}\text { Applicability } \\
\text { Always Some- Never } \\
\text { times }\end{array}$} & $\begin{array}{l}\text { Constraint Questions } \\
\text { Please indicate frequency by placing a checkmark in the appropriate column. }\end{array}$ \\
\hline & $\hat{\nabla}$ & & $\begin{array}{l}\text { How often is the health and safety cost a limiting constraint during the process of selecting } \\
\text { a decontamination technology? }\end{array}$ \\
\hline \multicolumn{4}{|c|}{ Operational Constraints } \\
\hline & $\hat{\nabla}$ & & $\begin{array}{l}\text { How often is the decontamination method used by a decontamination technology a limiting } \\
\text { constraint during the process of selecting a decontamination technology? (Examples of } \\
\text { decontamination methods include: mechanical, thermal, and chemical surface removal } \\
\text { methods.) }\end{array}$ \\
\hline & 4 & & $\begin{array}{l}\text { How often is the decontamination technology's ability to achieve a minimum production } \\
\text { rate a limiting constraint during the process of selecting a decontamination technology? }\end{array}$ \\
\hline & $\Leftrightarrow$ & & $\begin{array}{l}\text { How often are the decontamination technology's operating personnel requirements a } \\
\text { limiting constraint during the process of selecting a decontamination technology? }\end{array}$ \\
\hline & $\vdash$ & & $\begin{array}{l}\text { How often are the decontamination technology's utility requirements a limiting constraint } \\
\text { during the process of selecting a decontamination technology? }\end{array}$ \\
\hline \multirow[t]{2}{*}{ • } & & & $\begin{array}{l}\text { How often is the volume of waste generated by a decontamination technology a limiting } \\
\text { constraint during the process of selecting a decontamination technology? }\end{array}$ \\
\hline & $\hat{\nabla}$ & & $\begin{array}{l}\text { How often is the removal media type used by a decontamination technology a limiting } \\
\text { constraint during the process of selecting a decontamination technology? }\end{array}$ \\
\hline \multicolumn{4}{|c|}{ Health and Safety Constraints } \\
\hline & $\Rightarrow$ & & $\begin{array}{l}\text { How often is the use of respiratory protection by an operator of a decontamination } \\
\text { technology a limiting constraint during the process of selecting a decontamination } \\
\text { technology? }\end{array}$ \\
\hline & $\Leftrightarrow$ & & $\begin{array}{l}\text { How often is the use of a chemically resistant suit by an operator of a decontamination } \\
\text { technology a limiting constraint during the process of selecting a decontamination } \\
\text { technology? }\end{array}$ \\
\hline \multicolumn{4}{|c|}{ Other Constraints } \\
\hline & 1 & & $\begin{array}{l}\text { How often are the equipment portability requirements a limiting constraint during the } \\
\text { process of selecting a decontamination technology? }\end{array}$ \\
\hline & 4 & & $\begin{array}{l}\text { How often is the equipment availability time a limiting constraint during the process of } \\
\text { selecting a decontamination technology? }\end{array}$ \\
\hline \multicolumn{4}{|c|}{ Please list additional constraints and applicability below. } \\
\hline - & & & Cost of total project (sub-contracting) \\
\hline
\end{tabular}




\section{SECTION V. GENERAL QUESTIONS}

1) During the process of selecting a decontamination technology from a group of viable technology alternatives, what technology-specific information is required to determine the amount of health physics personnel needed for a given project? (Responses are shown below in italics.)

- This is dictated more by application environment than by technology.

- Does the technology add to the existing radiation dosage?

- Does the technology mobilize radiation contamination?

- How quickly does the technology remove radiation contamination?

- Materials used.

- Dispersion of contaminants.

- Secondary waste generated.

- Types and amounts of contamination present; radiological half-life.

- Amount of airborne contamination generated.

- Size of area affected.

- Type/number of equipment surveys to be performed.

- Application, productivity rate, waste streams generated, operating environment, labor requirements.

- Need to expand on characterization of problem.

2) During the process of selecting a decontamination technology from a group of viable decontamination technology alternatives, what technology-specific information ${ }^{2}$ is required to determine the amount of industrial hygienist personnel needed for a given project? (Responses are shown below in italics.)

- This is dictated more by application environment than by technology, but decontamination media must also be considered.

- What types of waste are generated?

- Are there any technology-specific chemical/physical hazards?

- Types and amounts of secondary waste generated.

- Dispersion of contaminants.

- Materials used.

${ }^{2}$ Technology-specific information is that information which pertains to the decontamination technology itself, NOT information pertaining to the decontamination site (i.e., site-specific information). 
- Types, forms and amounts of hazardous chemicals used (if any). MSDSs.

- Application, productivity rate, waste streams generated, operating environment, labor requirements.

\section{SECTION VI. USER PROFILE}

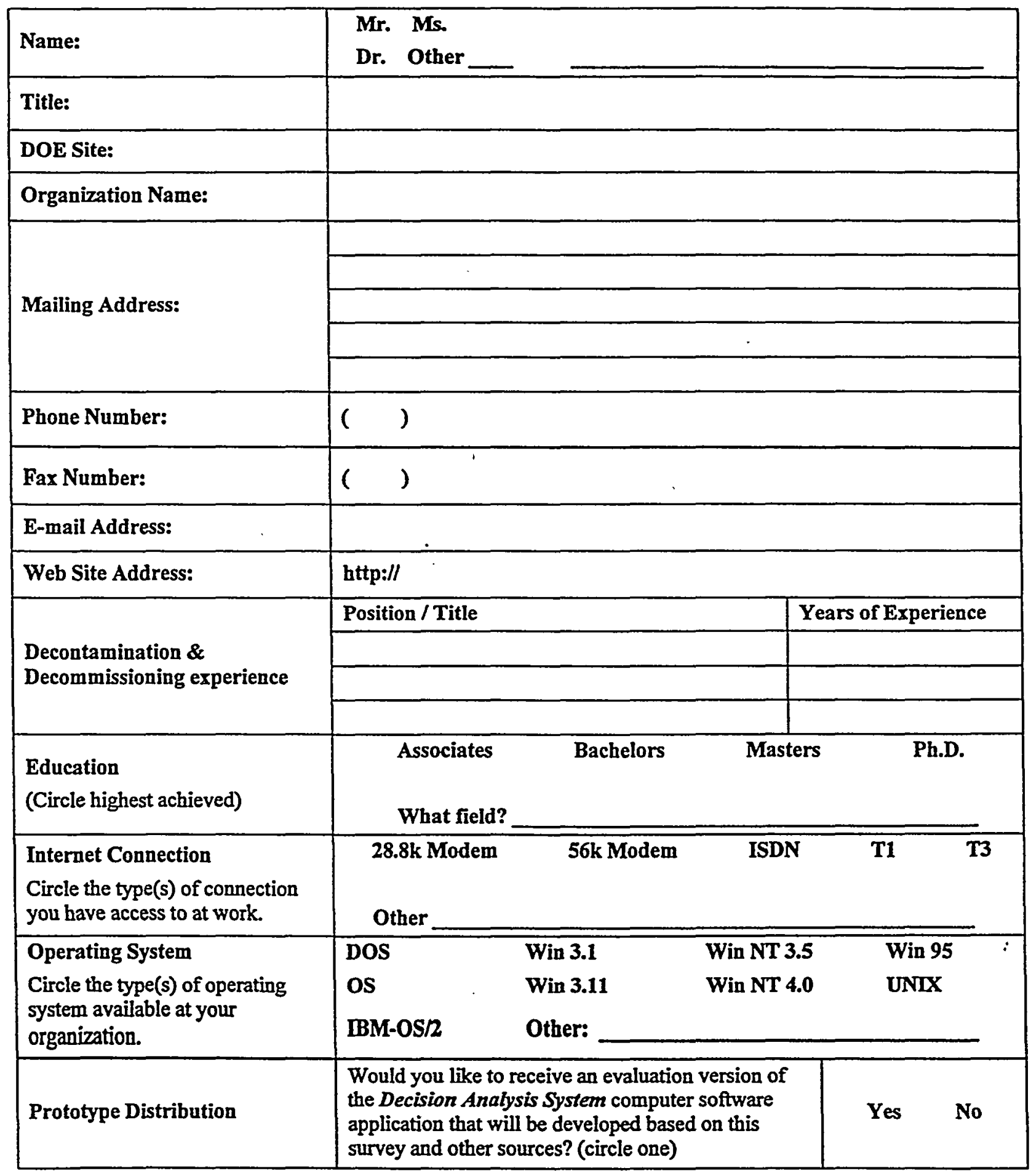


Table B.6.

1

Decontamination Technology Usage

(Text in italics are results of the survey of $D \& D$ professionals)

Please list the decontamination technology selections you have made within the last 5 years.

\begin{tabular}{|c|c|c|}
\hline Technology Name & Site & Reason Selected \\
\hline None & & \\
\hline None & & \\
\hline $\begin{array}{l}\text { None for field use. } \\
\text { For lab use: } \\
\text { Bio-decon of concrete; Liquid } \\
\text { nitrogen ultra high pressure } \\
\text { system; Laser Decon and LN, } \\
\text { laser assisted system. }\end{array}$ & & \\
\hline $\mathrm{CO}_{2}$ Decon & Rocky Flats B883 & $\begin{array}{l}\text { Effective on depleted } \\
\text { uranium contamination; } \\
\text { minimal secondary waste. }\end{array}$ \\
\hline Scabblers & Tested at various locations & $\begin{array}{l}\text { Effective at removing } \\
\text { surface contamination } \\
\text { from semi-porous } \\
\text { surfaces (eg. Concrete) }\end{array}$ \\
\hline Strippable coating paints & Rocky Flats Buildings 371 and 707 & $\begin{array}{l}\text { Effective method for } \\
\text { gloveboxes; low spread } \\
\text { of contaminants. }\end{array}$ \\
\hline
\end{tabular}


DATA AND FIELD DEFINITIONS 


\section{DATA AND FIELD DEFINITIONS}

Table C.1.

User/Project Identification

\begin{tabular}{|c|c|c|}
\hline Field Name & Description (Optional) & Data Type \\
\hline \multicolumn{3}{|l|}{ Data Inputted by User } \\
\hline $\begin{array}{l}\text { Area to be Decontaminated } \\
\text { (DA) }\end{array}$ & The size of the area to be decontaminated (in square feet). & String \\
\hline Contaminants of Concern & Defines the specific contaminants being decontaminated. & String \\
\hline $\begin{array}{l}\text { Health and Safety Costs } \\
\text { (HSC) }\end{array}$ & $\begin{array}{l}\text { A general dollar figure for providing H\&S costs on a per } \\
\text { hour basis. This includes Industrial Hygiene and Health } \\
\text { Physics support. }\end{array}$ & Monetary/hour \\
\hline $\begin{array}{l}\text { Labor Cost for a Technician } \\
\text { (LCT) }\end{array}$ & $\begin{array}{l}\text { The labor rate for one technician, which includes fringe } \\
\text { benefits. }\end{array}$ & Monetary/hour \\
\hline $\begin{array}{l}\text { Labor Cost for an Equipment } \\
\text { Operator(LCE) }\end{array}$ & $\begin{array}{l}\text { The labor rate for one equipment operator, which includes } \\
\text { fringe benefits. }\end{array}$ & Monetary/hour \\
\hline Project Acronym & Specific name of project at the DOE site. & String \\
\hline Site Name & Broad classification of DOE site. Select from pick list. & String \\
\hline $\begin{array}{l}\text { Site-Specific Waste Disposal } \\
\text { Cost (WDC) }\end{array}$ & $\begin{array}{l}\text { Cost in dollars per cubic feet. This includes container cost, } \\
\text { waste certification cost, and transportation cost. }\end{array}$ & Monetary \\
\hline User Initials & $\begin{array}{l}\text { Initials of user. Three digits are available. For first letter of } \\
\text { first name, middle name and last name. }\end{array}$ & String \\
\hline User Name & Name of person performing analysis. & String \\
\hline User Phone & Area code and seven digit phone number. & String \\
\hline User Títle & Title of the user & String \\
\hline Years in D\&D industry & Determine experience of user. & Integer \\
\hline \multicolumn{3}{|c|}{ User/Project Identifier Generated by DASD } \\
\hline Project Identifier & 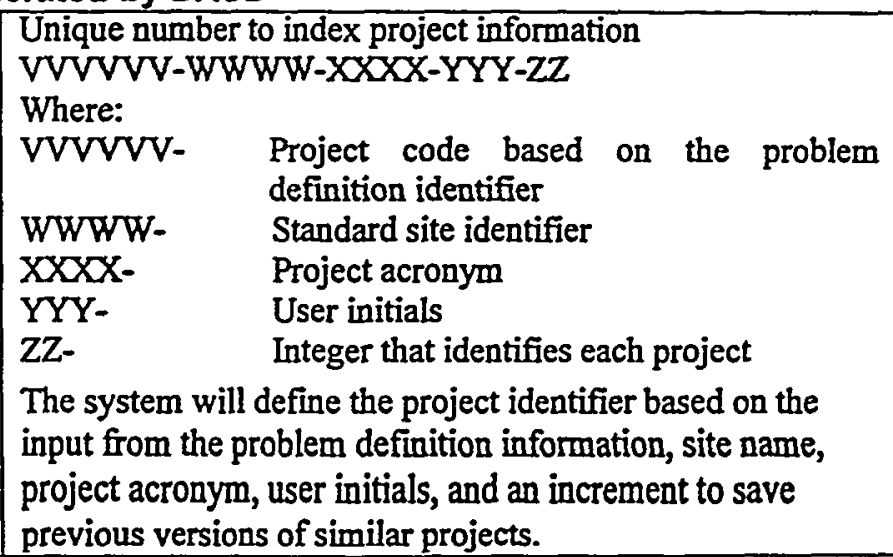 & String \\
\hline
\end{tabular}


Table C.2.

Sources of Data for SAT Tables

\begin{tabular}{|c|c|c|}
\hline Field Name & Description & Data Type \\
\hline \multicolumn{3}{|c|}{ Definition of Data Imported from MISD } \\
\hline Services Available & Which method will be used to obtain the technology? & String \\
\hline Basic System Capital Cost & $\begin{array}{l}\text { If the capital equipment will be purchased, what is the } \\
\text { maximum allowable price? }\end{array}$ & Monetary \\
\hline Utility Requirements & $\begin{array}{l}\text { Do you have a limitation on the type of utilities which can be } \\
\text { used in the facility? If yes, please delete the technologies that } \\
\text { do not meet your criteria. }\end{array}$ & Memo \\
\hline $\begin{array}{l}\text { Scarification Media Type } \\
\text { Used }\end{array}$ & $\begin{array}{l}\text { Do you have a limitation on the type of media used by the } \\
\text { system? If yes, please delete the technologies that do not } \\
\text { meet your criteria. }\end{array}$ & Memo \\
\hline Equipment Portability & $\begin{array}{l}\text { Is the portability of the equipment a limitation? If yes, please } \\
\text { delete the technologies that do not meet your criteria. }\end{array}$ & Memo \\
\hline Production Rate & $\begin{array}{l}\text { Is there a minimum production rate, which the technology } \\
\text { must achieve? If yes, enter input parameter. }\end{array}$ & String \\
\hline Waste Volume & $\begin{array}{l}\text { Is there a maximum waste volume the technology must not } \\
\text { create? This includes primary and secondary waste. }\end{array}$ & String \\
\hline Waste Volume & $\begin{array}{l}\text { Is there a maximum expenditure allowable for the disposal } \\
\text { of waste material? If yes, please enter the not to exceed } \\
\text { dollar value. }\end{array}$ & String \\
\hline Equipment Availability & $\begin{array}{l}\text { Is the availability of the equipment a concern to complete the } \\
\text { project? If yes, please delete the technologies that do not } \\
\text { meet your criteria. }\end{array}$ & Memo \\
\hline Required Personnel & $\begin{array}{l}\text { Is the number and type of personnel required to operate the } \\
\text { equipment a limiting factor? If yes, please delete the } \\
\text { technologies that do not meet your criteria. }\end{array}$ & $\begin{array}{l}\text { String, one for } \\
\text { each } \\
\text { classification of } \\
\text { personnel. }\end{array}$ \\
\hline Required Personnel & $\begin{array}{l}\text { Is there a maximum expenditure allowable for the labor } \\
\text { cost? If yes, please enter the not to exceed dollar value. }\end{array}$ & $\begin{array}{l}\text { String, one for } \\
\text { each } \\
\text { classification of } \\
\text { personnel. }\end{array}$ \\
\hline $\begin{array}{l}\text { Primary and Secondary } \\
\text { Waste }\end{array}$ & $\begin{array}{l}\text { Are there limitations on the characteristics of the waste } \\
\text { material generated? If yes, please delete the technólogies that } \\
\text { do not meet your criteria. }\end{array}$ & Memo \\
\hline $\begin{array}{l}\text { References, DOE site user, } \\
\text { and other site } \\
\text { references/publications }\end{array}$ & $\begin{array}{l}\text { Is the maturity of the technology a critical factor? If yes, } \\
\text { please delete the technologies that do not meet your criteria. }\end{array}$ & Memo \\
\hline Basic Equipment Description & Provide general description & Memo \\
\hline Benefits & List general benefits of technology. & Memo \\
\hline Limitations & List general limitations of the technology. & Memo \\
\hline Vendor Name & Vendor Name & String \\
\hline Company Address & Company Address & Memo \\
\hline
\end{tabular}




\begin{tabular}{|l|l|l|}
\hline Field Name & Description & Data Type \\
\hline \hline \multicolumn{2}{|l|}{ Definition of Data Imported from MISD } & \\
\hline \hline Company Phone & Company Phone & Integer \\
\hline Company Fax & Company Fax & Integer \\
\hline Email address & Email address & String \\
\hline Company Website Address & Company Website Address & String \\
\hline
\end{tabular}

Table C.3.

Cost Related Data Provided by User

\begin{tabular}{|c|c|c|c|}
\hline Acronym & Field Name & Description (Optional) & Data Type \\
\hline \multicolumn{4}{|c|}{ Site User Cost Related Data } \\
\hline $\begin{array}{l}\text { CAPREN } \\
(1-5)\end{array}$ & $\begin{array}{l}\text { Rental Rate per Hour for } \\
\text { Capital Equipment }\end{array}$ & $\begin{array}{l}\text { Rental rate for capital equipment. System can handle } \\
\text { up to } 5 \text { pieces of equipment. MISD will also provide } \\
\text { vendor name, company address, phone number, fax } \\
\text { number, equipment and support equipment } \\
\text { descriptions to aid in determining this value. }\end{array}$ & $\begin{array}{l}\text { Monetary/ } \\
\text { hour }\end{array}$ \\
\hline $\begin{array}{l}\text { CAPSV } \\
(1-5)\end{array}$ & $\begin{array}{l}\text { Salvage Value for } \\
\text { Capital Equipment }\end{array}$ & $\begin{array}{l}\text { The salvage value for capital equipment. System can } \\
\text { handle up to } 5 \text { pieces of equipment. MISD will also } \\
\text { provide vendor name, company address, phone } \\
\text { number, fax number, equipment and support } \\
\text { equipment descriptions to aid in determining this } \\
\text { value. }\end{array}$ & Monetary \\
\hline CPPE & $\begin{array}{l}\text { Cost for Personal } \\
\text { Protective Equipment } \\
\text { per hour. }\end{array}$ & $\begin{array}{l}\text { The aggregate total for the use of PPE for one } \\
\text { person. }\end{array}$ & $\begin{array}{l}\text { Monetaryl } \\
\text { hour }\end{array}$ \\
\hline$\overline{\mathrm{DA}}$ & $\begin{array}{l}\text { Surface Area to be } \\
\text { decontaminated }\end{array}$ & Area in square feet. & Real number \\
\hline$\overline{\mathrm{HSC}}$ & $\begin{array}{l}\text { H\&S Support Cost } \\
\text { (HSC) }\end{array}$ & $\begin{array}{l}\text { A general dollar figure for providing H\&S costs on a } \\
\text { per hour basis. This includes Industrial Hygiene and } \\
\text { Health Physics support. }\end{array}$ & $\begin{array}{l}\text { Monetaryl } \\
\text { hour }\end{array}$ \\
\hline IR & Interest Rate & $\begin{array}{l}\text { The interest rate used for capital purchases. (default } \\
\text { value .1) }\end{array}$ & $\begin{array}{l}2 \text { digit real } \\
\text { number }\end{array}$ \\
\hline LCE & $\begin{array}{l}\text { Labor Cost for an } \\
\text { Equipment Operator }\end{array}$ & $\begin{array}{l}\text { The labor rate for one equipment operator, which } \\
\text { includes fringe benefits. }\end{array}$ & $\begin{array}{l}\text { Monẹtary/ } \\
\text { hour }\end{array}$ \\
\hline$\overline{\text { LCT }}$ & $\begin{array}{l}\text { Labor Cost for a } \\
\text { Technician }\end{array}$ & $\begin{array}{l}\text { The labor rate for one technician, which includes } \\
\text { fringe benefits. }\end{array}$ & $\begin{array}{l}\text { Monetary/ } \\
\text { hour }\end{array}$ \\
\hline $\bar{N}$ & $\begin{array}{l}\text { Life in Hours for Total } \\
\text { Operation of Capital } \\
\text { Equipment }\end{array}$ & $\begin{array}{l}\text { The total number of hours the equipment can be used } \\
\text { before salvaged. }\end{array}$ & Real number \\
\hline
\end{tabular}




\begin{tabular}{|c|c|c|c|}
\hline Acronym & Field Name & Description (Optional) & Data Type \\
\hline $\begin{array}{l}\text { RENSE } \\
(1-5)\end{array}$ & $\begin{array}{l}\text { Rental Rate per hour for } \\
\text { Support Equipment }\end{array}$ & $\begin{array}{l}\text { The aggregate total for the rental of support } \\
\text { equipment per hour. System can handle up to } 5 \\
\text { pieces of equipment. MISD will also provide vendor } \\
\text { name, company address, phone number, fax number, } \\
\text { equipment and support equipment descriptions to aid } \\
\text { in determining this value. }\end{array}$ & $\begin{array}{l}\text { Monetary/ } \\
\text { hour }\end{array}$ \\
\hline $\begin{array}{l}\text { SEPUR } \\
(1-5)\end{array}$ & $\begin{array}{l}\text { Purchase Price for } \\
\text { Support Equipment }\end{array}$ & $\begin{array}{l}\text { The cost to purchase support equipment. System can } \\
\text { handle up to } 5 \text { pieces of equipment. MISD will also } \\
\text { provide vendor name, company address, phone } \\
\text { number, fax number, equipment and support } \\
\text { equipment descriptions to aid in determining this } \\
\text { value. }\end{array}$ & Monetary \\
\hline $\begin{array}{l}\text { SESV } \\
(1-5)\end{array}$ & $\begin{array}{l}\text { Salvage Value for } \\
\text { Support Equipment }\end{array}$ & $\begin{array}{l}\text { The salvage value for support equipment. System } \\
\text { can handle up to } 5 \text { pieces of equipment. MISD will } \\
\text { also provide vendor name, company address, phone } \\
\text { number, fax number, equipment and support } \\
\text { equipment descriptions to aid in determining this . } \\
\text { value. }\end{array}$ & Monetary \\
\hline $\mathrm{TH}$ & $\begin{array}{l}\text { Number of Training } \\
\text { Hours per Person }\end{array}$ & $\begin{array}{l}\text { Based on site specific training requirements for an } \\
\text { individual. } \\
\text { MISD will also provide vendor name, company } \\
\text { address, phone number, fax number, equipment and } \\
\text { support equipment descriptions to aid in determining } \\
\text { this value. }\end{array}$ & Integer \\
\hline THPO & $\begin{array}{l}\text { Total Hours of Possible } \\
\text { Operation per Year }\end{array}$ & $\begin{array}{l}\text { The total possible number of hours of operation for } \\
\text { the technology for a year period. }\end{array}$ & Real number \\
\hline TRAN & Transportation Cost & $\begin{array}{l}\text { The aggregate total of transportation costs for capital } \\
\text { and support equipment to/from site. } \\
\text { MISD will also provide vendor name, company } \\
\text { address, phone number, fax number, equipment and } \\
\text { support equipment descriptions to aid in determining } \\
\text { this value. }\end{array}$ & Monetary \\
\hline WDC & Waste Disposal Cost & $\begin{array}{l}\text { Cost in dollars per cubic feet. This includes container } \\
\text { cost, waste certification cost, and transportation cost. }\end{array}$ & Monetary \\
\hline
\end{tabular}


Table C.4.

DASD Field Definitions for Data Imported from MISD

\begin{tabular}{|c|c|c|c|}
\hline Acronym & Field Name & Description (Optional) & Data Type \\
\hline $\begin{array}{l}\text { CAPPUR } \\
(1-5)\end{array}$ & $\begin{array}{l}\text { Purchase Price for } \\
\text { Capital Equipment }\end{array}$ & $\begin{array}{l}\text { The total for the purchase of capital equipment. } \\
\text { System can handle up to } 5 \text { pieces of equipment. }\end{array}$ & Monetary \\
\hline$\overline{\mathrm{CON}}$ & Consumable Cost & $\begin{array}{l}\text { The cost for media and other consumables, which are } \\
\text { needed to provide for operation of the equipment. }\end{array}$ & $\begin{array}{l}\text { Monetary/ } \\
\text { hour }\end{array}$ \\
\hline$\overline{\mathrm{DMOBT}}$ & Demobilization Time & The time in hours to demobilize the equipment. & $\begin{array}{l}\text { Real number } \\
\text { in hours }\end{array}$ \\
\hline $\mathrm{MC}$ & Maintenance Cost & $\begin{array}{l}\text { The cost to maintain the equipment. Major } \\
\text { replacement parts are not included. }\end{array}$ & $\begin{array}{l}\text { Monetaryl } \\
\text { hour }\end{array}$ \\
\hline MOBT & Mobilization Time & The time in hours to mobilize the equipment. & $\begin{array}{l}\text { Real number } \\
\text { in hours }\end{array}$ \\
\hline NLCE & $\begin{array}{l}\text { Number of Equipment } \\
\text { Operators }\end{array}$ & $\begin{array}{l}\text { The number of equipment operators needed to } \\
\text { operate the equipment. }\end{array}$ & Integer \\
\hline NLCT & Number of Technicians & $\begin{array}{l}\text { The number of technicians needed to operate the } \\
\text { equipment. }\end{array}$ & Integer \\
\hline PROD & Production Rate & $\begin{array}{l}\text { The production rate for the decontamination } \\
\text { equipment. }\end{array}$ & $\begin{array}{l}\text { Real number } \\
\text { Square feet } \\
\text { hour }\end{array}$ \\
\hline WV & Waste Volume & $\begin{array}{l}\text { The waste volume created by using the technology. } \\
\text { This includes primary and secondary waste. }\end{array}$ & $\begin{array}{l}\text { Real number } \\
\text { Cubic feet }\end{array}$ \\
\hline
\end{tabular}


Table C.5.

DASD Field Definitions for Computed Costs

\begin{tabular}{|c|c|c|c|}
\hline Acronym & Field Name & Description (Optional) & Data Type \\
\hline$\overline{C A P A M O R}$ & $\begin{array}{l}\text { Amortized Purchase } \\
\text { Price for Capital } \\
\text { Equipment }\end{array}$ & $\begin{array}{l}\text { Using the formula for present value an amortized } \\
\text { purchase price for capital equipment is calculated. } \\
\text { MaSD will also provide company name, company } \\
\text { address, phone number, fax number, equipment and } \\
\text { support equipment descriptions to aid in determining } \\
\text { this value. }\end{array}$ & Monetary \\
\hline CAP_REN & $\begin{array}{l}\text { Value for Renting } \\
\text { Capital Equipment }\end{array}$ & $\begin{array}{l}\text { Dollar value to rent capital equipment. } \\
\text { MISD will also provide company name, company } \\
\text { address, phone number, fax number, equipment and } \\
\text { support equipment descriptions to aid in determining } \\
\text { this value. }\end{array}$ & Monetary \\
\hline EIT & Effective Interest Rate & $\begin{array}{l}\text { The interest rate is used in conjunction with the total } \\
\text { possible number of hours for operation per year to } \\
\text { calculate the effective interest rate. }\end{array}$ & Real number \\
\hline $\mathrm{HO}$ & Hours of Operation & $\begin{array}{l}\text { Using the size of the area to be decontaminated and } \\
\text { the equipment production rate, the hours of operation } \\
\text { can be calculated. }\end{array}$ & Real number \\
\hline $\mathrm{HS}$ & Health and Safety Cost & $\begin{array}{l}\text { The total cost to supply health and safety support for } \\
\text { the project. }\end{array}$ & Monetary \\
\hline$\overline{L C}$ & Labor Cost & $\begin{array}{l}\text { Using the labor cost per hour and the hours of } \\
\text { operation the labor cost can be calculated. }\end{array}$ & Monetary \\
\hline$\overline{\mathrm{LCH}}$ & Labor Cost per Hour & $\begin{array}{l}\text { The total labor cost per hour including equipment } \\
\text { operators and technicians. }\end{array}$ & $\begin{array}{l}\text { Monetaryl } \\
\text { hour }\end{array}$ \\
\hline $\mathrm{MOB}$ & $\begin{array}{l}\text { Mobilization and } \\
\text { Demobilization Cost }\end{array}$ & $\begin{array}{l}\text { The total cost to mobilize and demobilize the } \\
\text { decontamination technology. }\end{array}$ & Monetary \\
\hline$\overline{O C}$ & Operations Cost & $\begin{array}{l}\text { Factors related to health and safety, mobilization and } \\
\text { demobilization, operations and maintenance cost, } \\
\text { personal protective equipment, support equipment, } \\
\text { training and transportation are summed to get the } \\
\text { total operations cost. }\end{array}$ & Monetary \\
\hline OMC & $\begin{array}{l}\text { Operating and } \\
\text { Maintenance Cost }\end{array}$ & $\begin{array}{l}\text { The total cost to operate and maintain the } \\
\text { technology. Costs include maintenance, media, and } \\
\text { other consumables. } \\
\text { MISD will also provide the description of the PPE } \\
\text { and environmental conditions used during the } \\
\text { assessment. }\end{array}$ & Monetary \\
\hline PPE & $\begin{array}{l}\text { Personal Protective } \\
\text { Equipment }\end{array}$ & $\begin{array}{l}\text { The total cost to supply PPE to the equipment } \\
\text { operators and the technicians. }\end{array}$ & Monetary \\
\hline SEAMOR & $\begin{array}{l}\text { Amortized Purchase } \\
\text { Price for Support } \\
\text { Equipment }\end{array}$ & $\begin{array}{l}\text { Using the formula for present value, an amortized } \\
\text { purchase price for support equipment is calculated. } \\
\text { MISD will also provide company name, company } \\
\text { address, phone number, fax number, equipment and } \\
\text { support equipment descriptions to aid in determining } \\
\text { this value. }\end{array}$ & Monetary \\
\hline
\end{tabular}




\begin{tabular}{|c|c|c|c|}
\hline Acronym & Field Name & Description (Optional) & Data Type \\
\hline SE_REN & $\begin{array}{l}\text { Value for Renting } \\
\text { Support Equipment. }\end{array}$ & $\begin{array}{l}\text { Dollar value to rent support equipment. } \\
\text { MISD will also provide company name, company } \\
\text { address, phone number, fax number, equipment and } \\
\text { support equipment descriptions to aid in determining } \\
\text { this value. }\end{array}$ & Monetary \\
\hline TRAIN & Training Cost & $\begin{array}{l}\text { The total cost to train the equipment operators and } \\
\text { technicians. }\end{array}$ & Monetary \\
\hline$\overline{W D}$ & Waste Disposal Cost & The total cost to dispose of waste material. & Monetary \\
\hline
\end{tabular}


DASD GRAPHICAL USER INTERFACES (GUI) 


\section{DASD GRAPHICAL USER INTERFACES (GUI)}

This Appendix contains illustrations of the various graphical user interfaces (GUT) that are used by DASD to prompt system users for input, and to feedback information to the users.

\section{D\&D PROJECT PROBLEM SET DEFINITION}

In order to identify technologies that may be suitable for a given project, three parameters must first be established. They are: surface type, surface geometry, and removal capacity. Figure D.1 below illustrates the graphical user interface (GUI) that prompts the user for input. The user must select one sub-category from each of the three main categories.

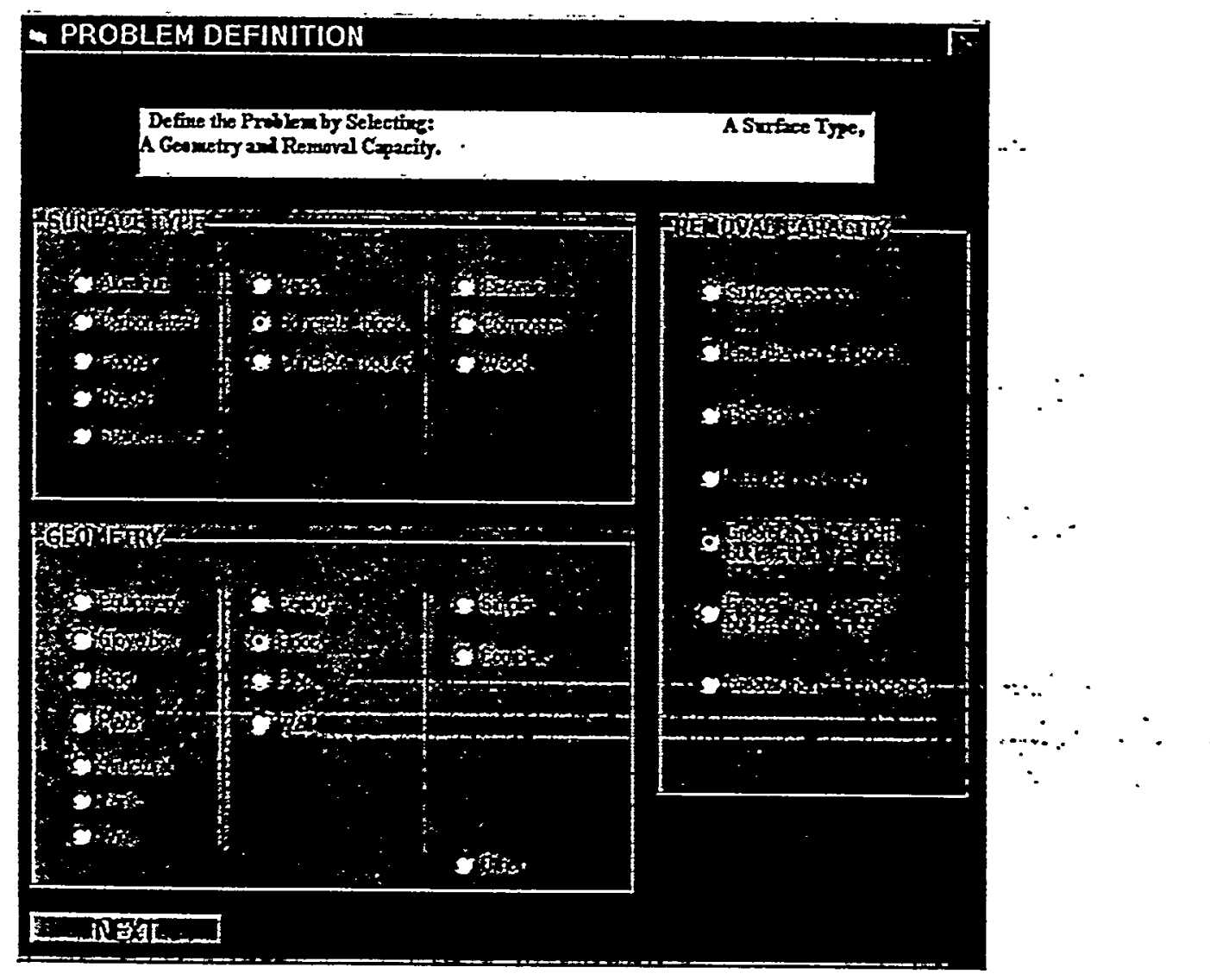

Figure D.1. Problem Set Definition. The user inputs parameters that describe the nature of their D\&D project.

\section{HISTORICAL USERS DATABASE}

The Historical Users Database will allow users to access the records of previously-defined problem sets or define a new problem set using system default values. This minimizes data entry 
duplication and reduces the time required to complete the decision analysis simulation. The key information that is captured at this point includes:

- Project Identifier

- Site Name

- Project Acronym

- User Initials

- Area to be Decontaminated

Figure D.2 illustrates the GUI that prompts users to enter the required information.

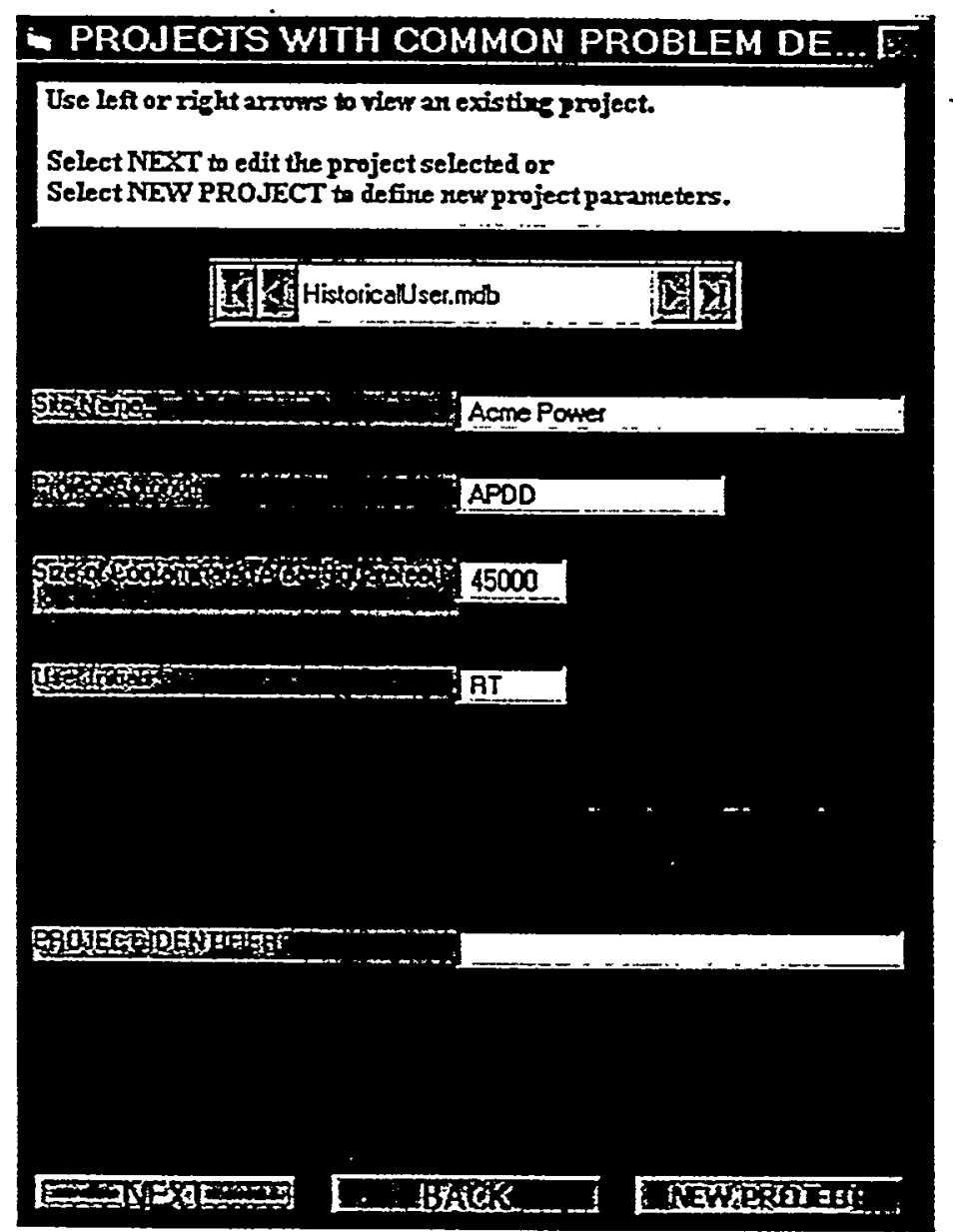

Figure D.2. The user is shown projects with similar problem sets and may use one of these as a template query, or create a new query. The project is then assigned a Project ID number by DASD. 


\section{USER/PROJECT IDENTIFICATION}

Users and their individual projects are identified by DASD through unique User/Project Identification numbers. DASD prompts the user (Figure D.3) to provide user/project-specific identification information which includes: site name, project acronym, user name, user initials, user phone, user title, area to be decontaminated (in square feet) and number of years in D\&D industry. This information aids in characterizing the types of decontamination problem sets evaluated by the user and the system. By characterizing the decontamination problem sets, future users may be able to simplify the system execution sets by implementing previously stored information.

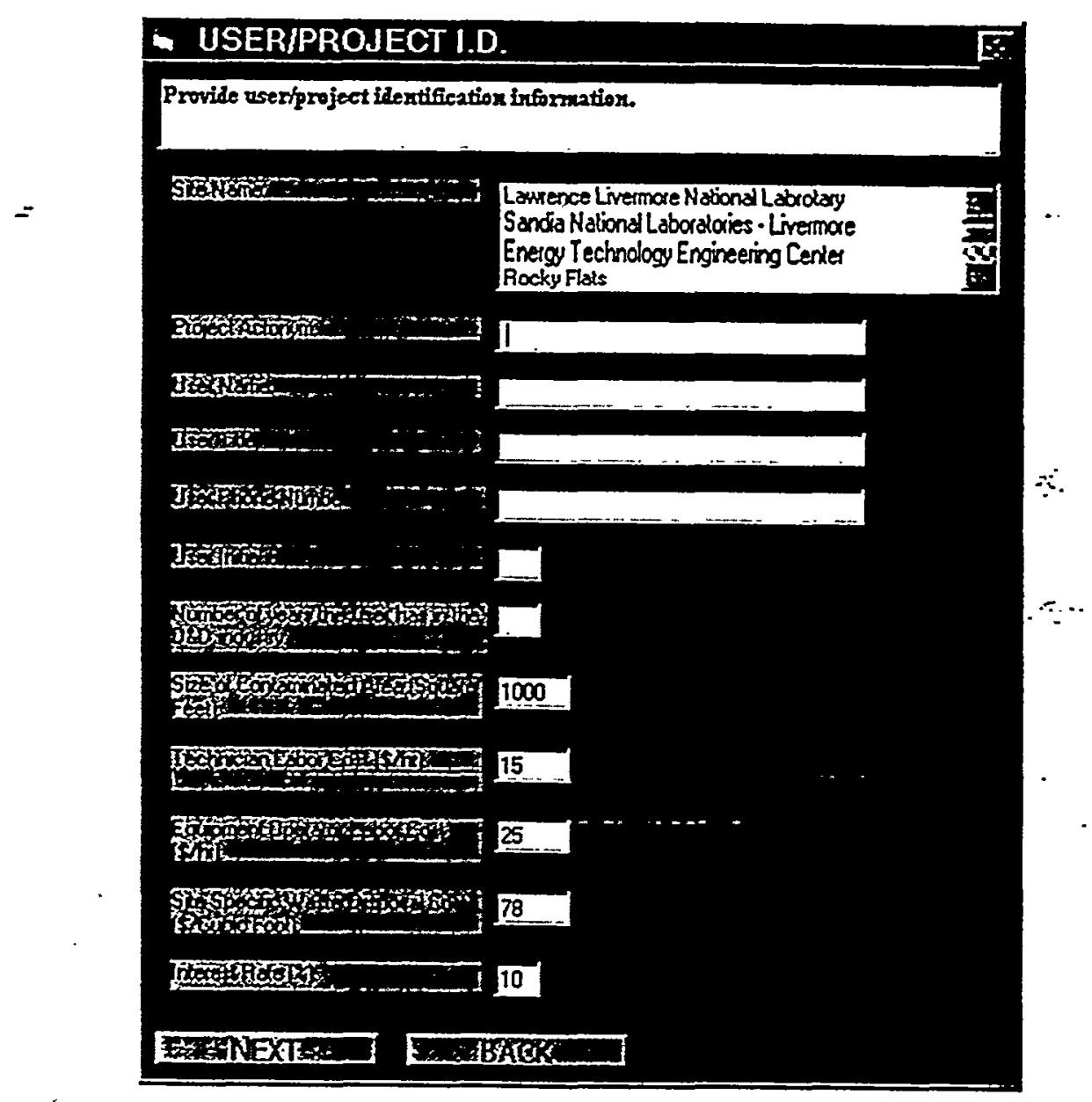

Figure D.3. The user inputs company, site and project data that are stored in a user profile database. Project- and sitespecific parameters are also inputted.

\section{SCREENING OF ALTERNATIVE TECHNOLOGIES TABLE}

After the user has defined the specific problem and has provided the user/project identification information, DASD provides a preliminary list of candidate technologies (Figure D.4) which allows the user to perform a Screening of Alternative Technologies (SAT). The goal of this 
screening process is to allow the user to narrow the number of technology alternatives that go forward through the technology selection detailed process. Reducing the number of candidate technologies at this early stage reduces the time required to complete the selection process. Figure D.5 is an example of the results of a preliminary screening that identifies only those technologies that may be rented, and eliminates those that must be purchased.

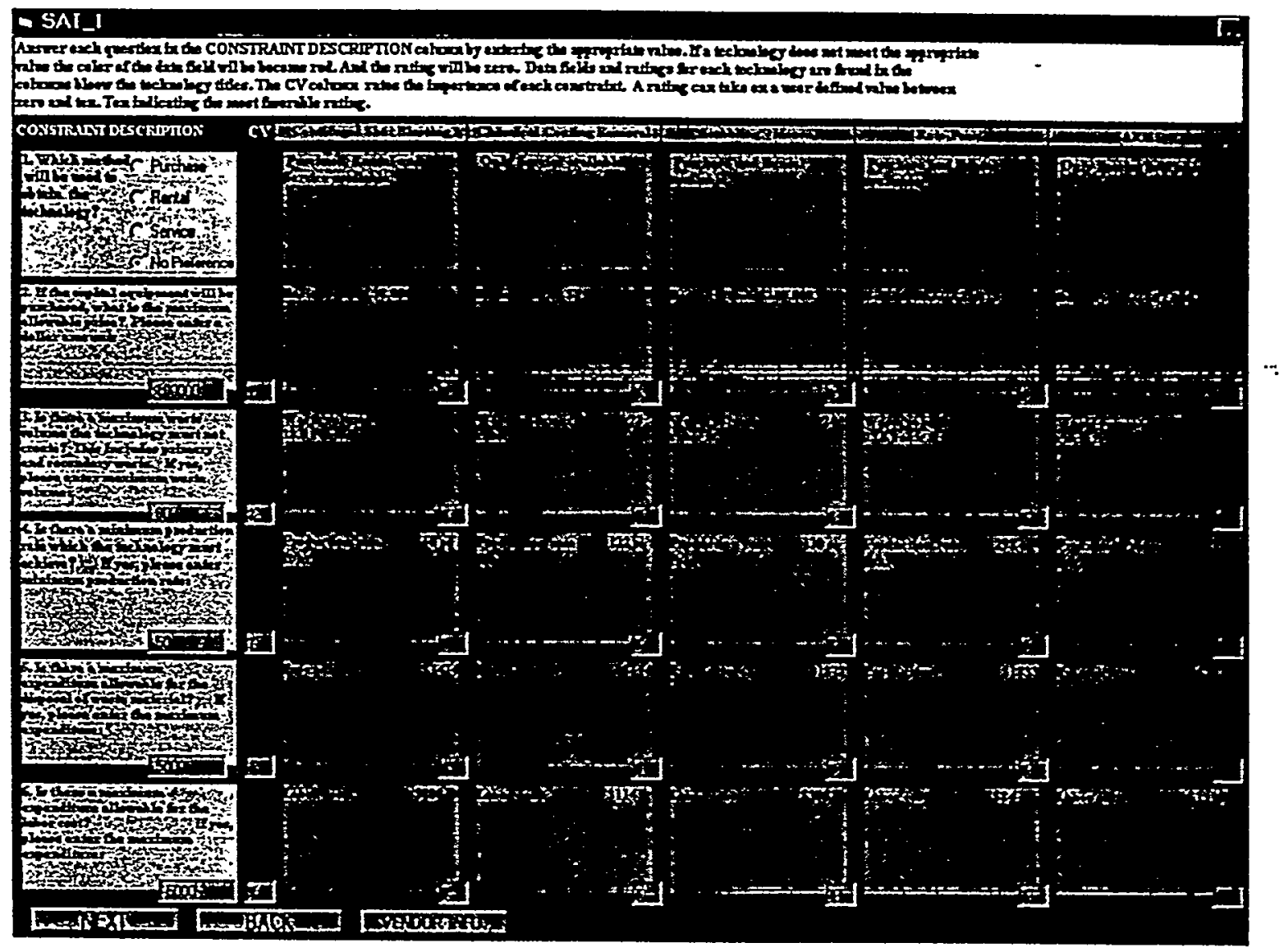

Figure D.4. SAT table showing initial list of potential technology solutions.

The user then reviews the individual technology constraints (column 1 in SAT) to complete the preliminary screening process. These range from absolute constraints to constraints that are minimally important to the technology selection process. Constraints are rated on a Criticality Index scale from zero to ten. The lower the rating, the less important the constraint is to the user. If a technology is rated ten, this indicates an absolute constraint, and it is critically important that the technology meets this criterion to be considered a viable solution. For example, if a technology can only be purchased, it is disqualified if the user is only interested in renting equipment. If a technology is rated zero, this denotes a criterion that does not have to be met. Criticality values are entered by the user in column 2 of the SAT Table (Figures D.4 and D.5).

SATs generated by DASD are structured as follows: 
- The table consists of a two-dimensional matrix. Each row represents a constraint, and each column lists a candidate technology that satisfies the initial problem set defined for the project (see Table 15).

- The first column describes the nature of each constraint and prompts the user to quantify or qualify his/her specific constraints.

- The second column shows the criticality index for each constraint. DASD assigns a default value of 5 for this field, and the user may modify it to reflect the importance of this constraint to his/her specific circumstances.

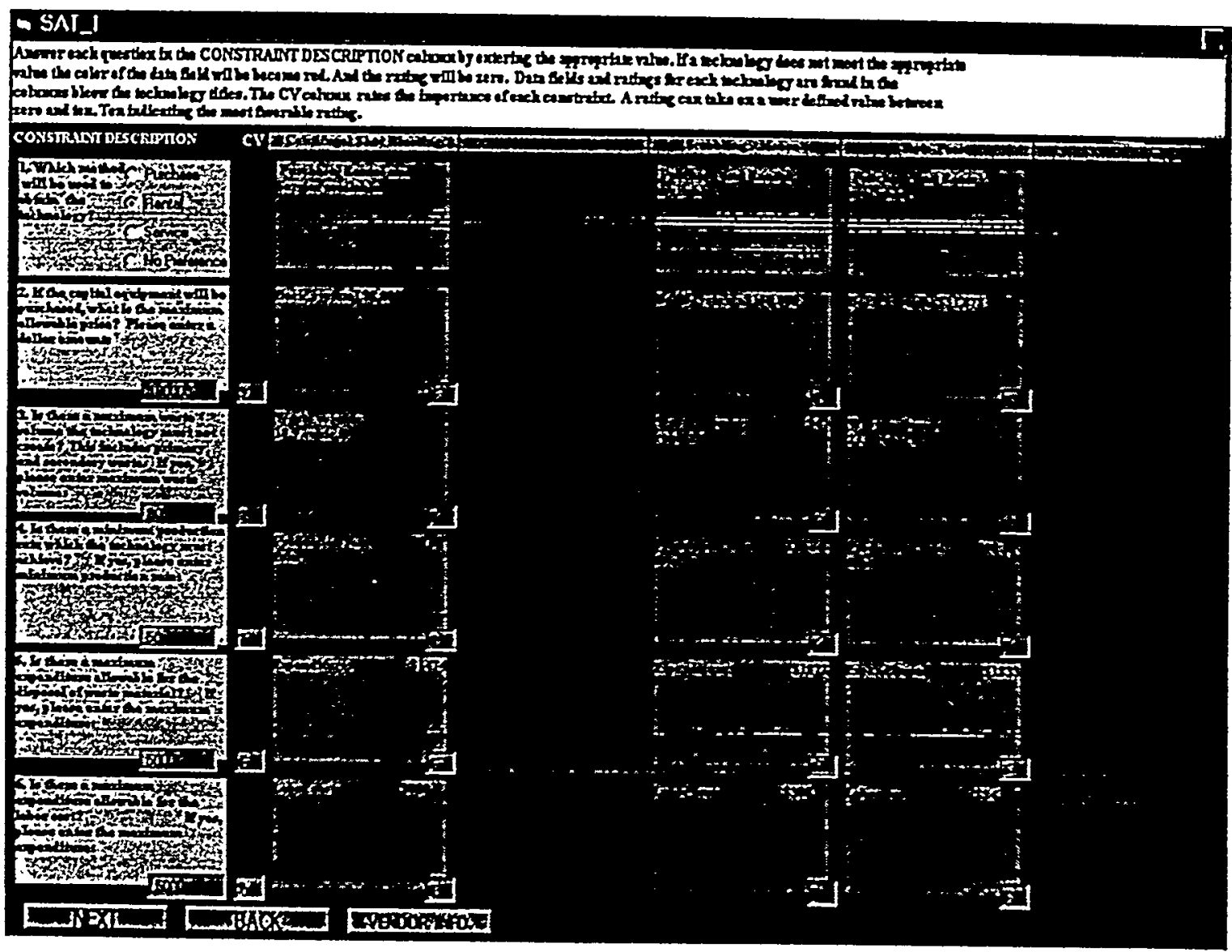

Figure D.5. SAT Table showing only those technologies that satisfy critical constraints (e.g., if equipment can only be rented). Technologies that do not qualify are suppressed.

- The cells in columns three through seven of the table describe the characteristics of each candidate technology as they relate to each constraint listed in the first column. Each cell also contains a prompt where the user may indicate his or her preference for each technology characteristic based on how it affects each of his or her specific constraints. The preference scale runs from zero (least preferred) to ten (most preferred) and if the user does not input a value, DASD assigns a default value of five. 
- Technology characteristics that do not satisfy user-defined constraints are highlighted in red (e.g., if the cost of purchasing the equipment exceeds the user's budget) (Figure D.4).

- Based on the technology characteristics and features summarized in the SAT matrix, the user may, at this stage, manually eliminate technologies that are not foreseen to be viable solutions due to the constraints that they impose (e.g., if the technology is not available when it is needed). To do so, the user simply double clicks on the name of the technology at the top of the matrix and it will be suppressed (Figure D.5). Eliminated technologies may be reinstated by double clicking on their names a second time. The intent is to distill the number of technologies to a manageable number (ideally three or less) before proceeding with more detailed analysis.

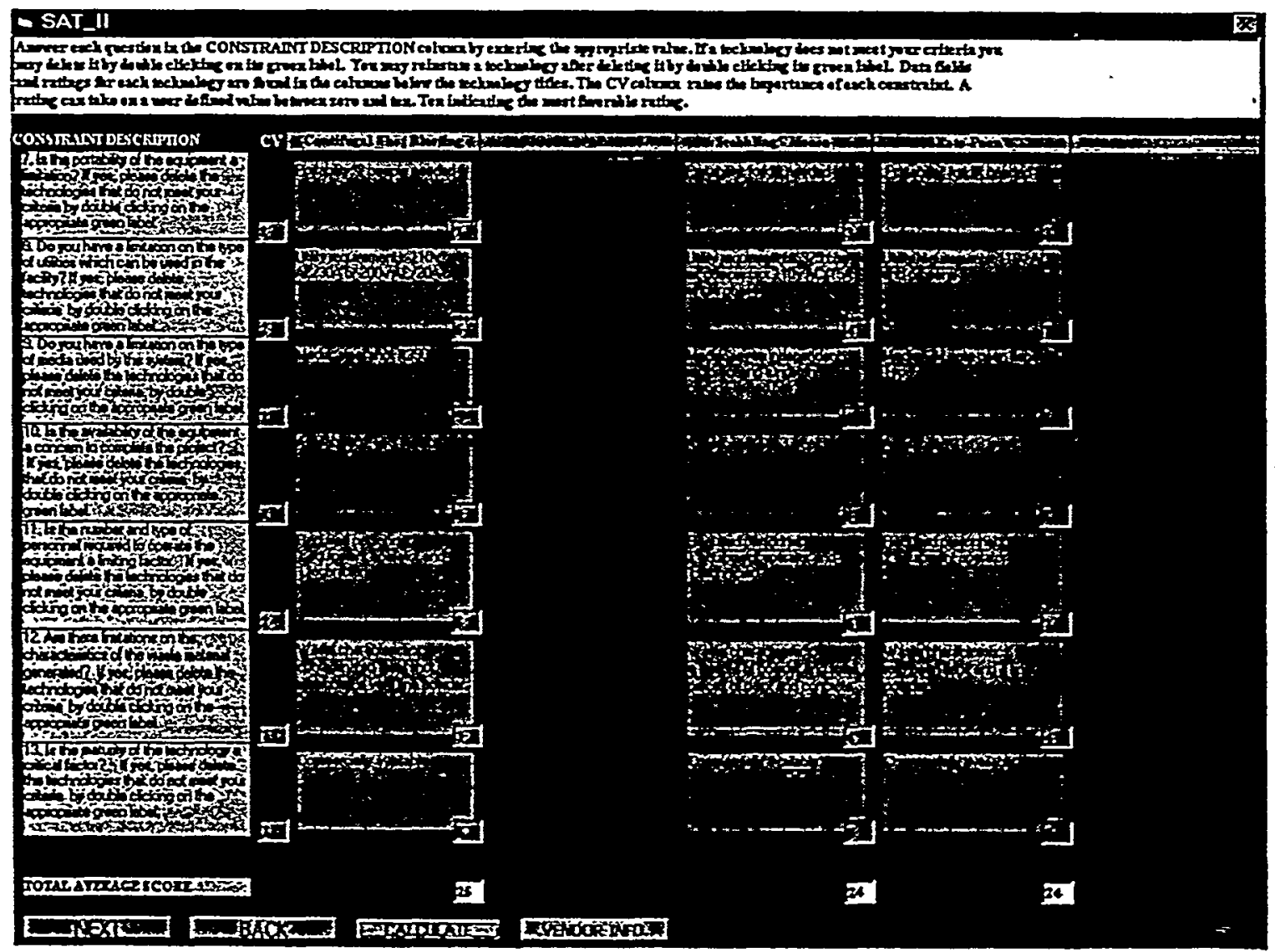

Figure D.6. Additional constraints rated in the SAT by the user. This is a continuation from Figure D.5.

- The total score for each technology alternative is shown in the last row of the matrix.

- Vendor-provided data on each technology (e.g., environmental conditions and vendor contact information) may be accessed simply by clicking on the vendor information button at the bottom of the SAT screen and then selecting the vendor's name from a list (see Figure D.6). 


\section{DECISION ANALYSIS MODEL}

During the process of selecting a decontamination technology, a decision-maker must logically organize and systematically compare data on a group of viable technology alternatives in order to decide which is the most appropriate solution. In the Decision Analysis Model employed by DASD, decontamination technology data elements that are to be examined are first organized into logical data categories as shown in Table D.1.

Table D.1.

Decision Analysis Model Technology Data Hierarchy

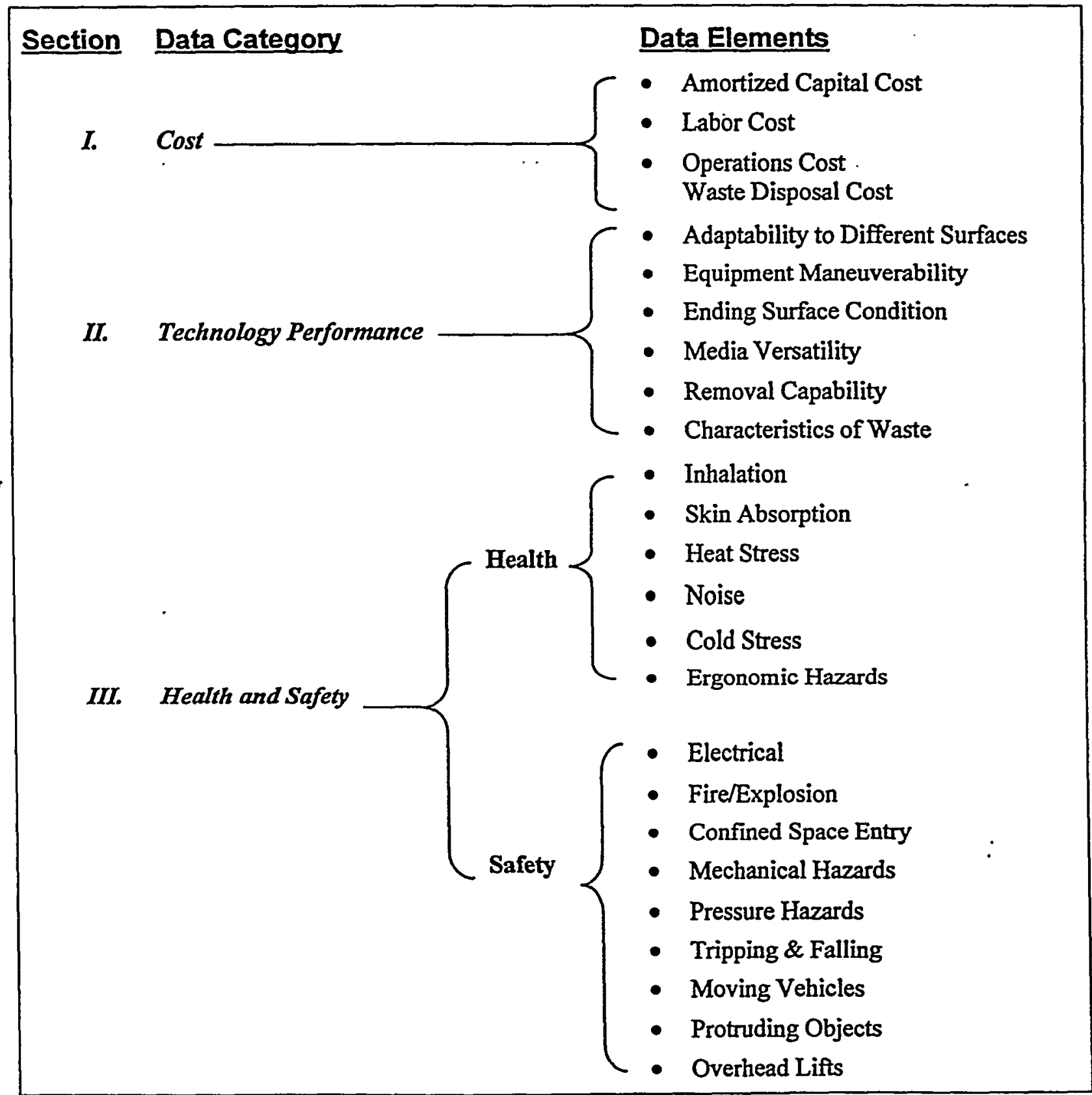


This decision analysis model is used by DASD to graphically illustrate to the user all the decision factors that are taken into account. and to allow the user to rate the relative importance of each factor. Figure D.7 shows the model, and Figures D.8 and D.9 are examples of the GUIs that prompt the user to rate individual factors when a data category is selected.

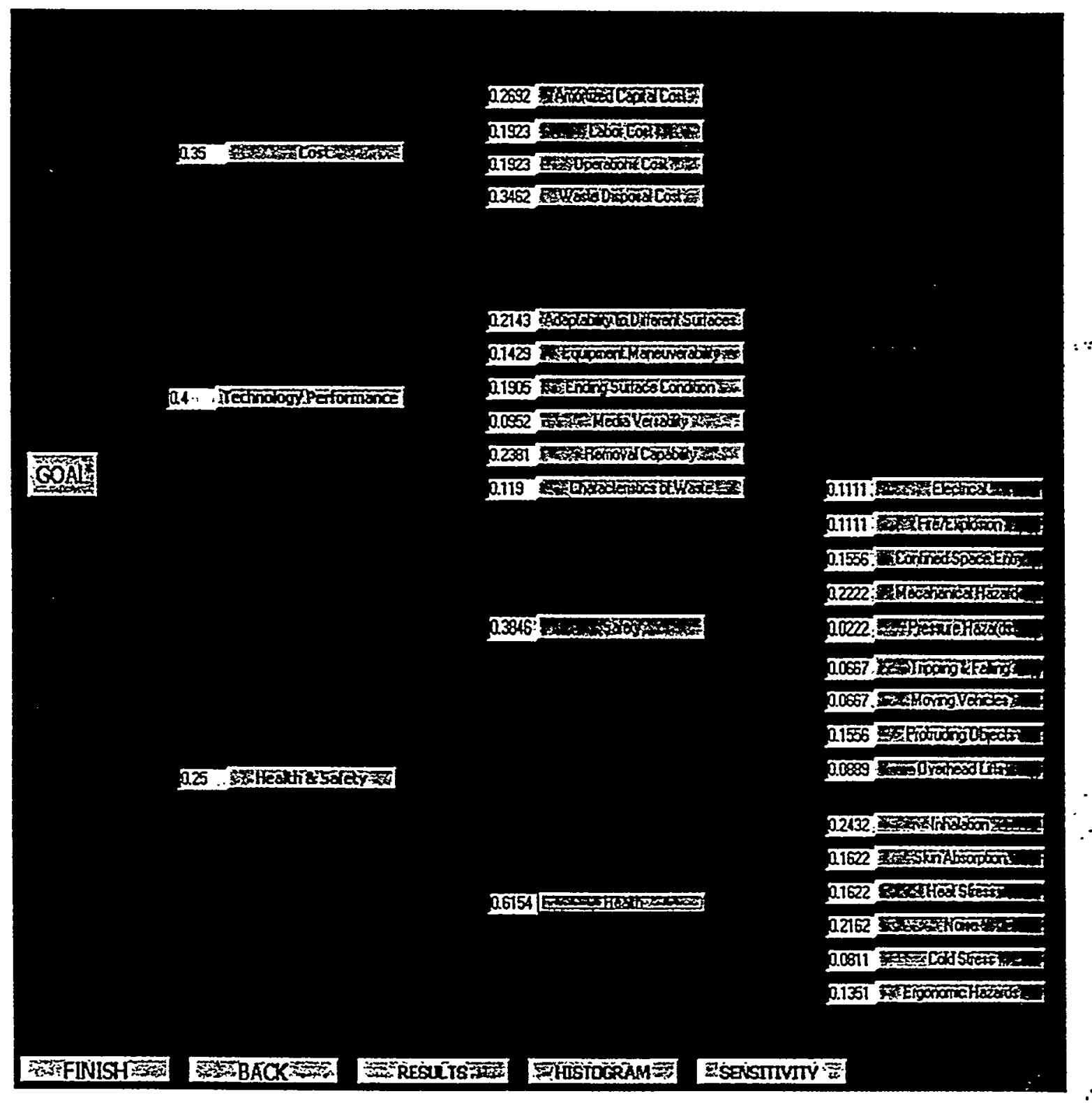

Figure D.7. Decision Analysis Model showing the hierarchy of data categories and decision factors considered by DASD.

To rate each factor, the user selects the category containing that particular factor and is then prompted to rate the importance of all factors within the category. For example, to rate 
technology cost, the user selects "Goal" and is then prompted to rate all three major factors that affect the project's goals, i.e. cost, technology performance, and health and safety (Figure D.8).

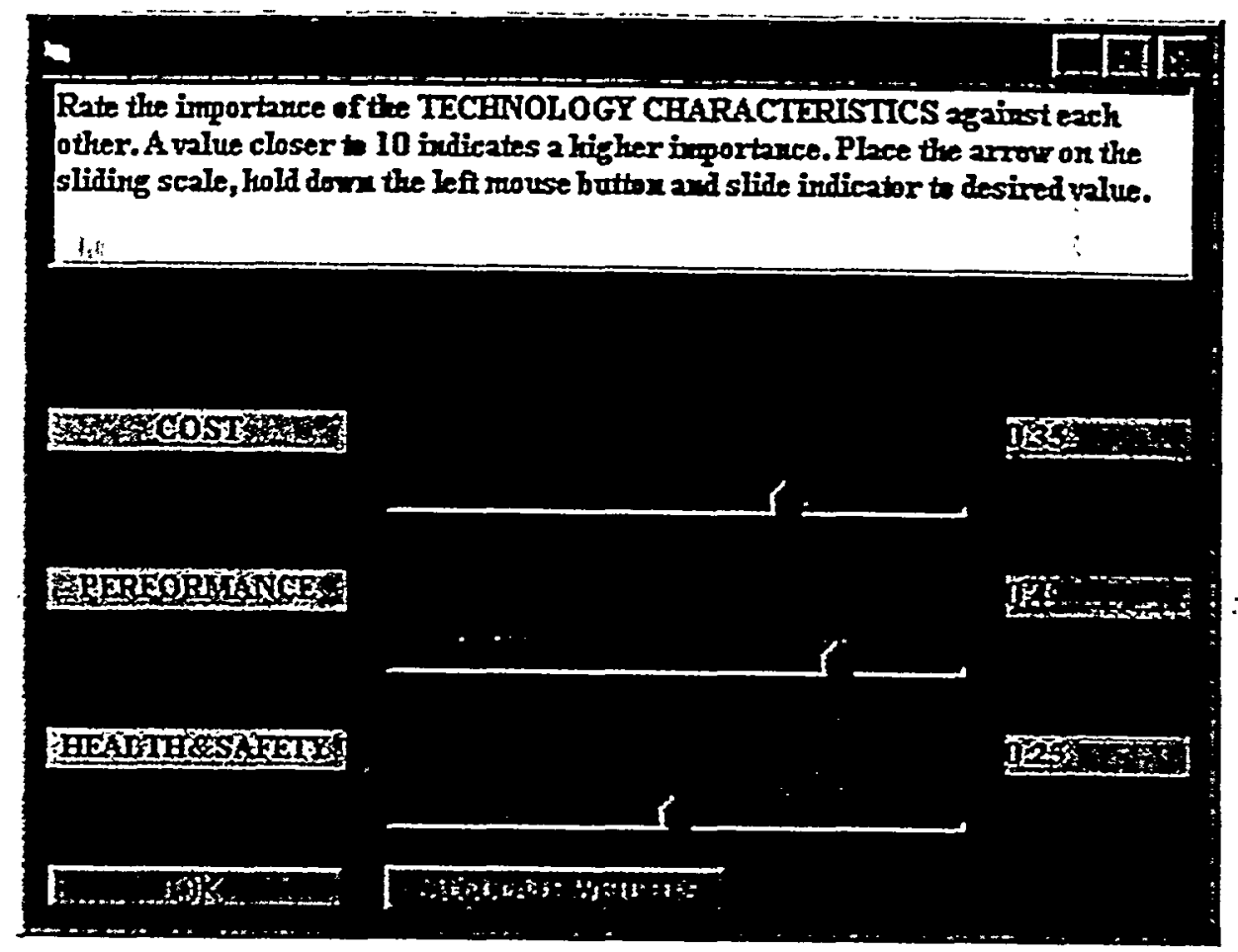

Figure D.8. The user rates the decision factors that impact the goals of the project.

\section{TECHNOLOGY COST EVALUATION}

To facilitate the review of the cost elements associated with each technology, four cost categories have been developed. The four main cost categories are capital cost, waste disposal cost, labor cost and operations cost. These costs are calculated by employing user-provided information and information from the MISD technology database. The system will allow the user to modify any cost element in the system, tailoring the results to the user's specific problem and experience. The user then evaluates the cost categories by rating their importance on a scale of zero (least important) to ten (most important) (Figure D.8). Details on the formulas used by DASD for calculating costs can be found in Appendix D. 


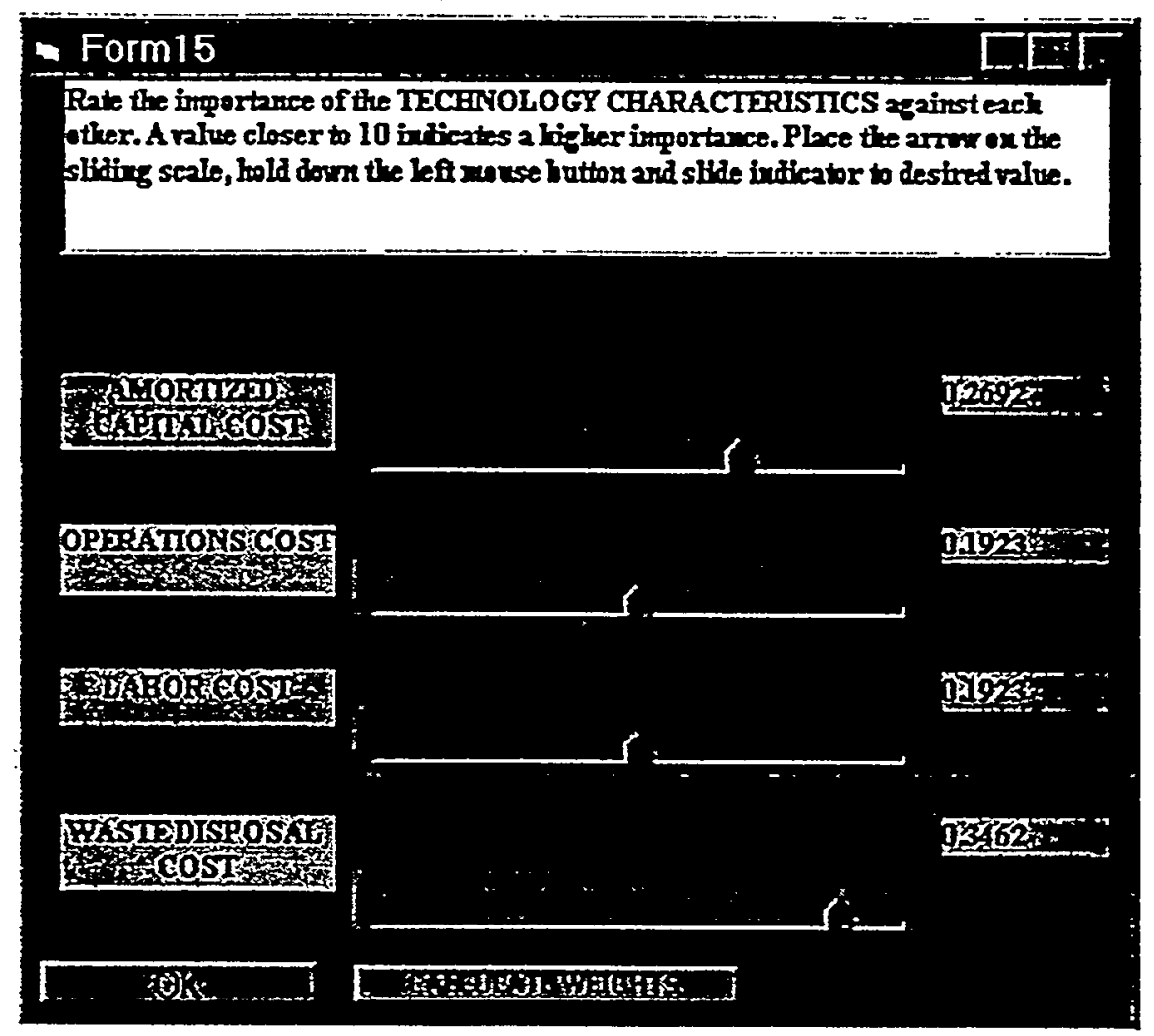

Figure D.8. The user rates the importance of each cost category on a scale of one to ten.

This process is repeated for all remaining data categories until each decision factor is assigned a rating.

After decision factors are rated, the cost associated with each can then be calculated. The user selects the cost factor to be calculated and is prompted by DASD to enter relevant data that is required to complete the calculation. Figure D.9 shows the data input screen that must be completed for each candidate technology in order that DASD may calculate the cost of purchasing or renting them. 


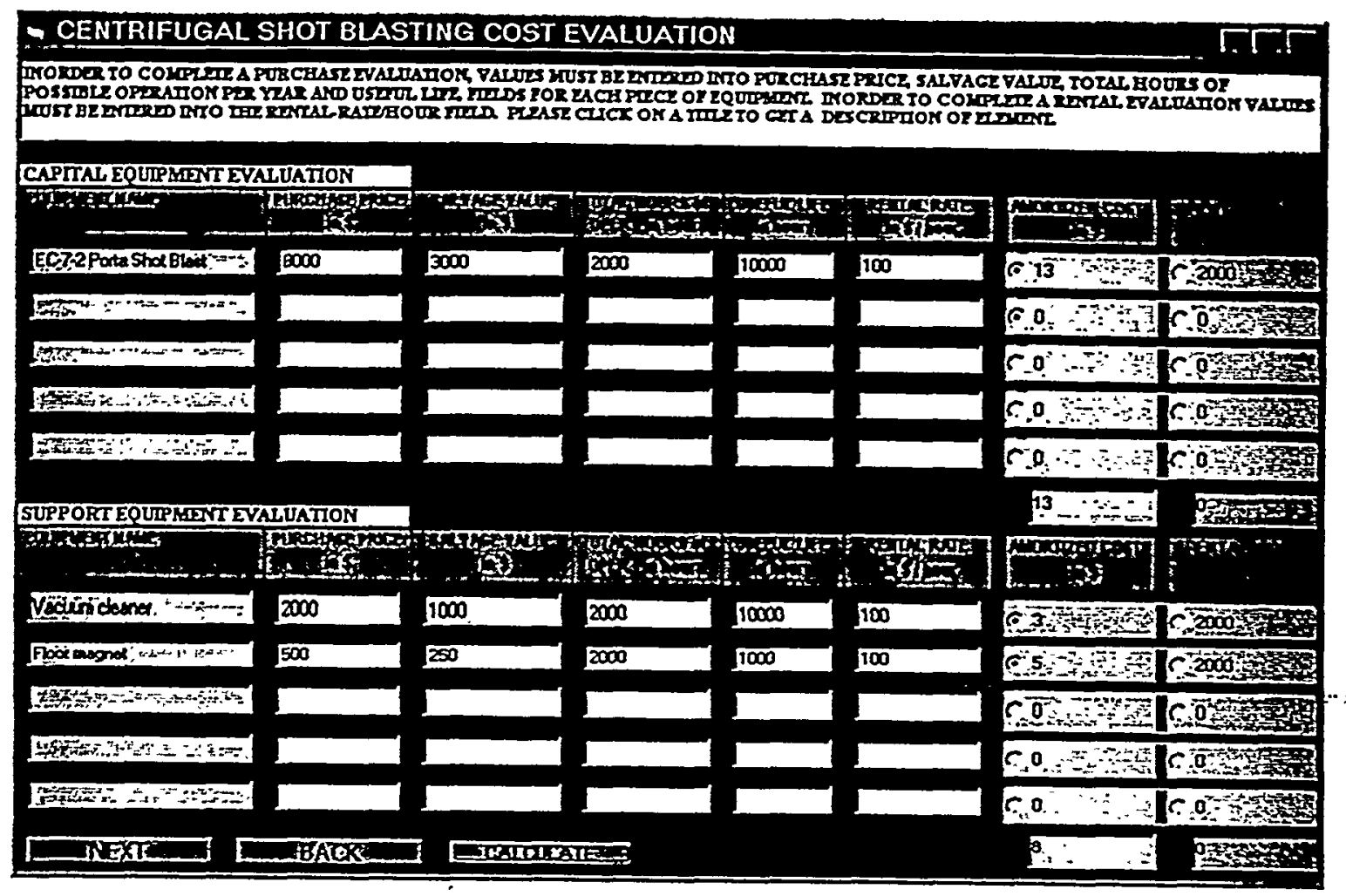

Figure D.9. User inputs data required to calculate the purchase and/or rental costs of a candidate technology and any required support equipment.

The user then repeats this process for each of the remaining cost elements. These are shown in Figures D.10 and D.11.

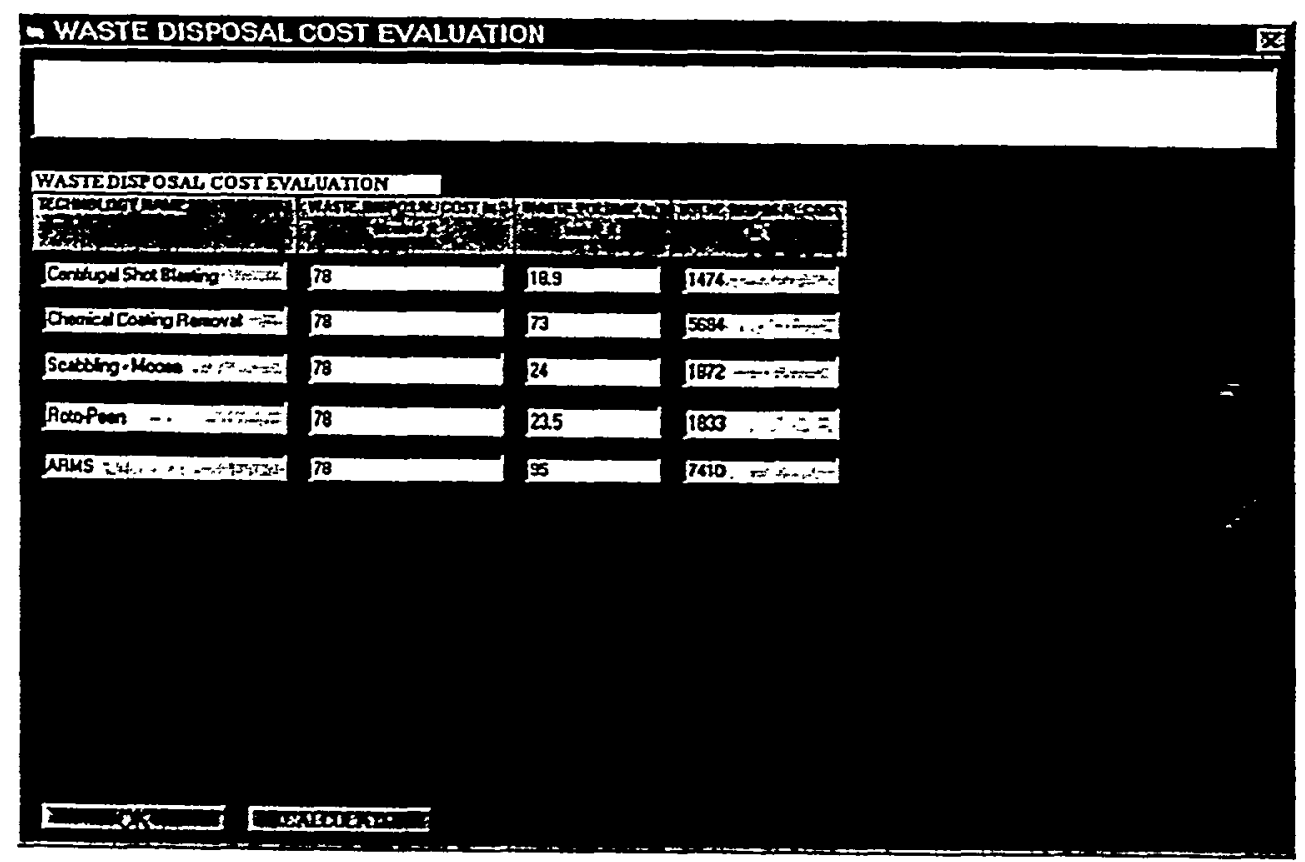

Figure D.10. User inputs data for calculating waste disposal costs. 


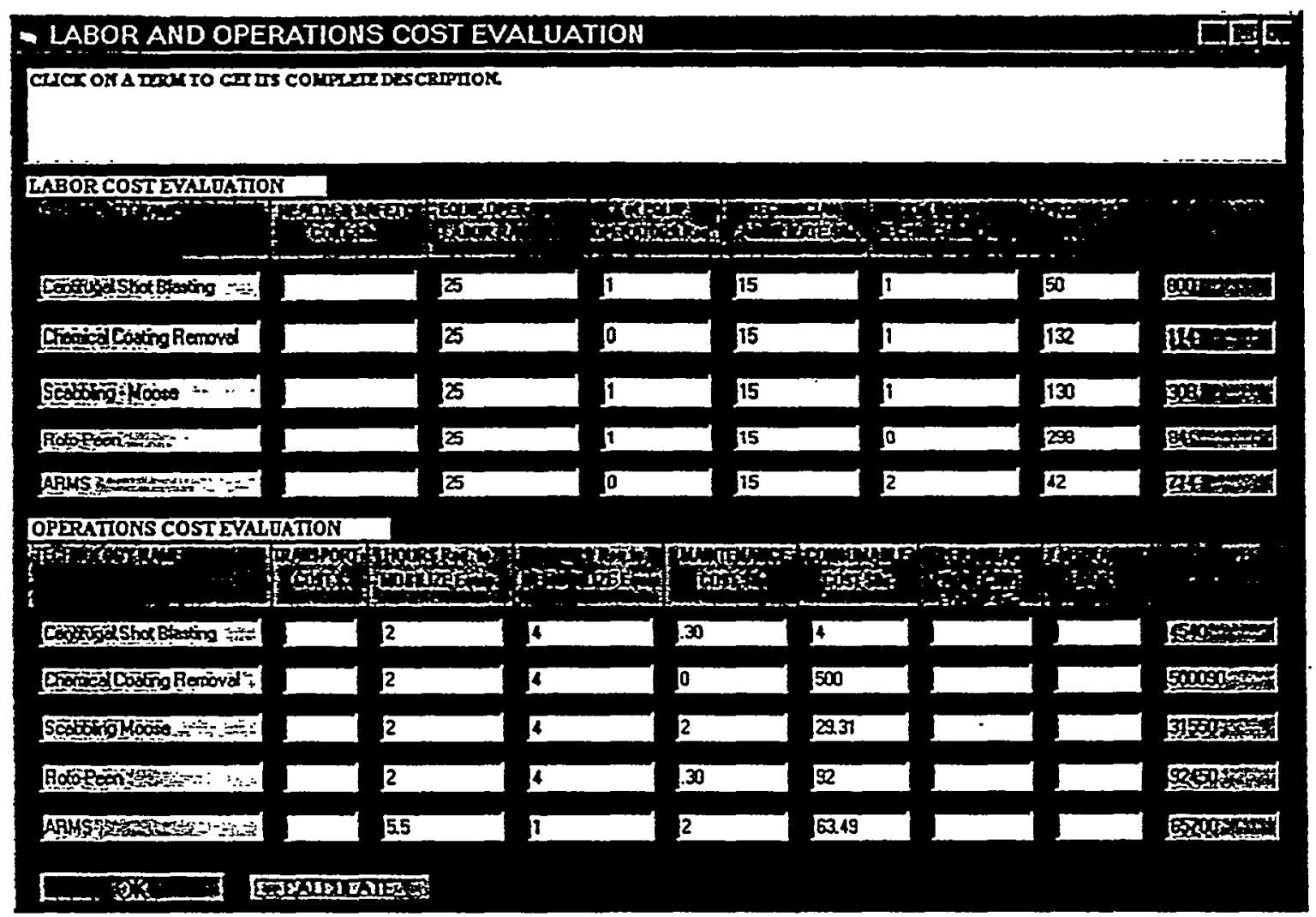

Figure D.11. User inputs data required for calculating labor and operations costs.

The user continues this process until all qualitative and quantitative factors are rated and/or costed. The user then requests DASD to display overall technology rating results. These results can be displayed in either a graphical scalar rating format (Figure D.12) or a graphical histogram format (Figure D.13).

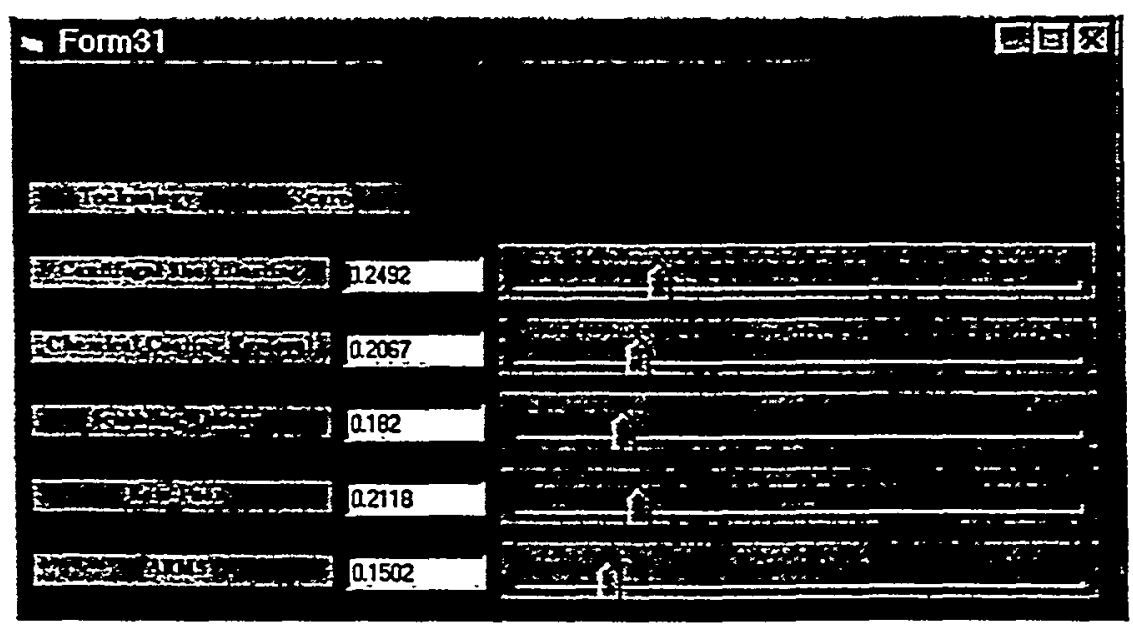

Figure D.12. Scalar display of overall technology rating results. 


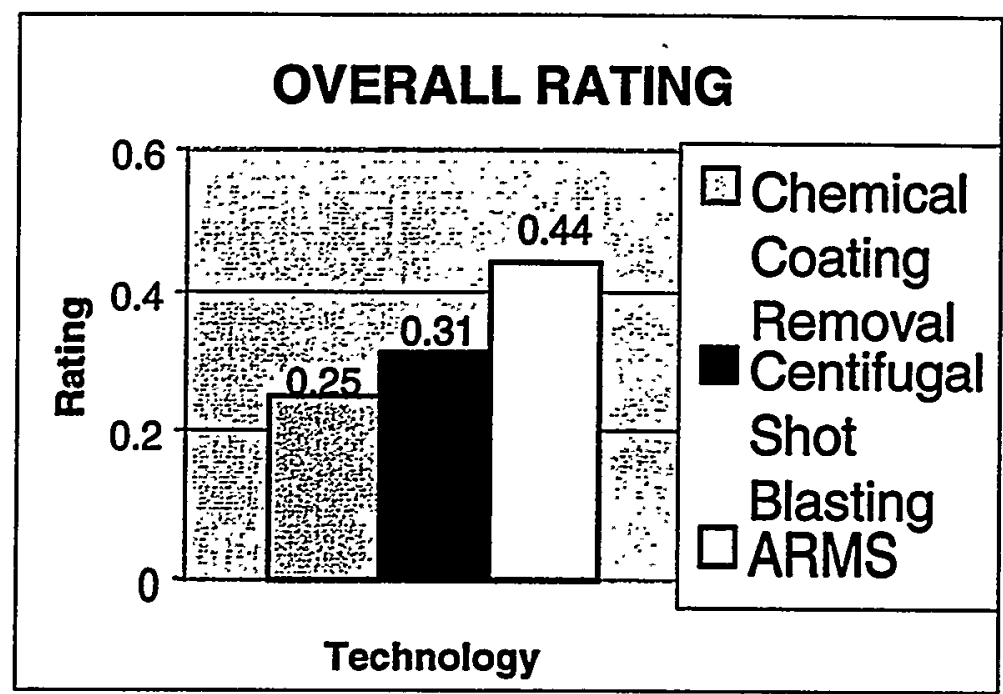

Figure D.13. Histogram display of overall technology rating results.

In addition, the user may display a sensitivity analysis chart (Figure D.14) that identifies the critical factors that may easily alter the highest-ranked technology(s). This information is important to defend judgments and focus on sensitive areas before making a final technology decision.

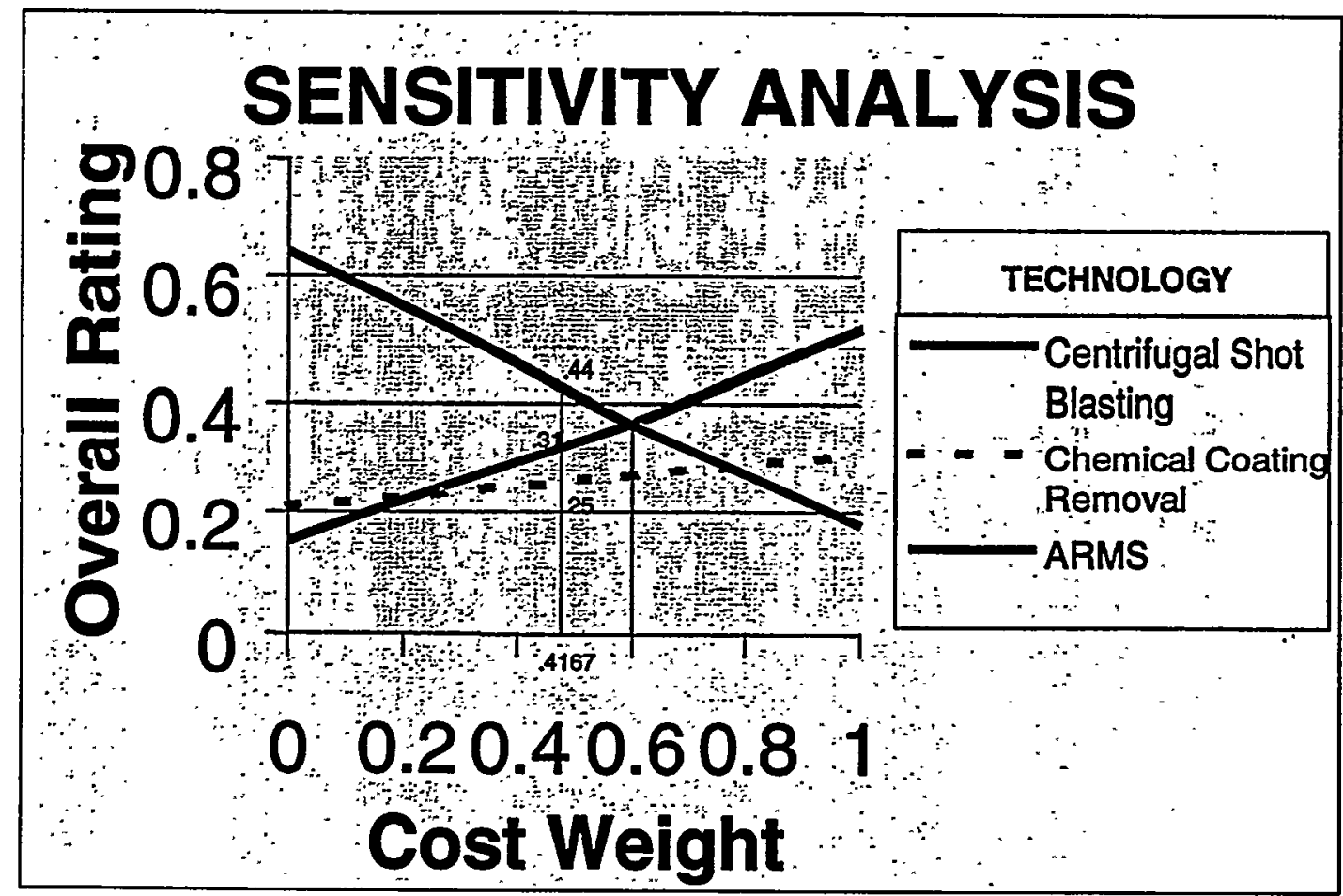

Figure D.14. Sensitivity analysis shows the effect that a change in the weighting of cost factors might have on the overall rating of candidate technologies. 


\section{APPENDIXE}

FORMULAS USED FOR CALCULATING COSTS 


\section{FORMULAS USED FOR CALCULATING COSTS}

During the completion of the SAT process, the user specifies whether capital equipment will be purchased, rented or a combination of the two options. If the purchase option is specifically checked (no capital equipment will be rented) then equation (1) will be used. If the rental option is specifically checked (no capital equipment will be purchased) then equation (2) will be used. If the combination of the two options is chosen, the user must specify which equipment will be purchased and which equipment will be rented.

The following formula will be used to calculate the amortized capital cost (CAPAMOR) or capital rental cost (CAP_REN):

$$
\begin{array}{ll}
\text { CAP_REN } \Rightarrow & \text { Calculated Value for Rental of Capital Equipment } \\
\text { CAPAMOR } \Rightarrow & \text { Calculated Amortized Value for Purchase Price of Capital } \\
& \text { Equipment over the period of " } \mathrm{n} \text { " hours. } \\
\text { CAPPUR } & \Rightarrow \text { Purchase Price for Capital Equipment } \\
\text { CAPREN } & \Rightarrow \text { Rental Rate per Hour for Capital Equipment } \\
\text { CAPSV } & \Rightarrow \text { Salvage Value for Capital Equipment } \\
\text { DA } & \Rightarrow \text { Area to be Decontaminated } \\
\text { EIT } & \Rightarrow \text { Effective Interest Rate } \\
\text { HO } & \Rightarrow \text { Hours of Operation } \\
\text { IR } & \Rightarrow \text { Interest Rate (Default value .1) } \\
n & \Rightarrow \text { Life in Hours of Total Operation } \\
\text { PROD } & \Rightarrow \text { Production Rate } \\
\text { THPO } & \Rightarrow \text { Total Hours of Possible Operation per Year }
\end{array}
$$

(1) $\mathrm{CAPAMOR}=(\mathrm{CAPPUR}-(\mathrm{CAPSV} /(1+\mathrm{EIT}))) * \mathrm{EIT} /\left(1-\left(1 /(1+\mathrm{EIT})^{\mathrm{n}}\right)\right) * \mathrm{HO}$

Or

(2) CAP_REN $=$ CAPREN $*$ HO

Where: $E I T=I R T H P O \quad H O=D A / P R O D$

The following formula will be used to calculate the operations cost (OC): 


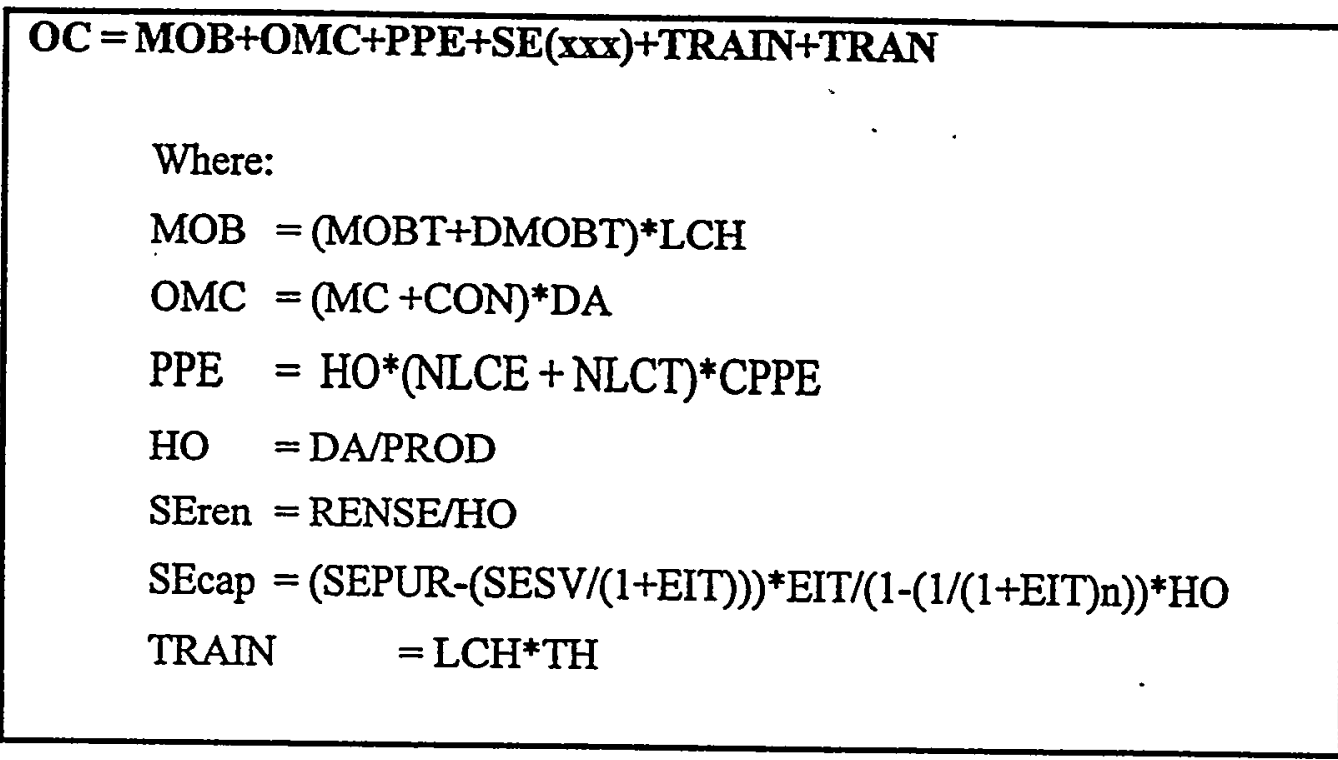

$\begin{array}{ll}\text { CON } & \Rightarrow \text { Consumable Cost } \\ \text { CPPE } & \Rightarrow \text { Cost for Personal Protective Equipment per Hour } \\ \text { DA } & \Rightarrow \text { Area to be Decontaminated } \\ \text { DMOBT } & \Rightarrow \text { Demobilization Time } \\ \text { EIT } & \Rightarrow \text { Effective Interest Rate (where } \Rightarrow \text { EIT }=\text { IRTHPO) } \\ \text { HO } & \Rightarrow \text { Hours of Operation } \\ \text { IR } & \Rightarrow \text { Interest Rate (Default }=1) \\ \text { LCH } & \Rightarrow \text { Labor Cost per Hour } \\ \text { MC } & \Rightarrow \text { Maintenance Cost } \\ \text { MOB } & \Rightarrow \text { Mobilization and Demobilization Cost } \\ \text { MOBT } & \Rightarrow \text { Mobilization Time } \\ \text { n } & \Rightarrow \text { Life in Hours of Total Operation } \\ \text { NLCE } & \Rightarrow \text { Number of Equipment Operators } \\ \text { NLCT } & \Rightarrow \text { Number of Technicians } \\ \text { OC } & \Rightarrow \text { Operations Cost } \\ \text { OMC } & \Rightarrow \text { Operating and Maintenance Cost } \\ \text { PPE } & \Rightarrow \text { Personal Protective Equipment Cost } \\ \text { PROD } & \Rightarrow \text { Production Rate } \\ \text { RENSE } & \Rightarrow \text { Rental Rate per Hour for Support Equipment } \\ \text { SEAMOR } & \Rightarrow \text { Support Equipment Cost Purchase } \\ & \end{array}$




\begin{tabular}{|c|c|}
\hline SE_REN & $\Rightarrow$ Support Equipment Cost Rental \\
\hline SEPUR & $\Rightarrow$ Purchase Price for Support Equipment \\
\hline SESV & $\Rightarrow$ Salvage Value for Support Equipment \\
\hline TH & $\Rightarrow$ Number of Training Hours per Person \\
\hline THPO & $\Rightarrow$ Total Hours of Possible Operation per Year \\
\hline TRAIN & $\Rightarrow$ Training Cost \\
\hline TRAN & $\Rightarrow$ Transportation Cost \\
\hline \multicolumn{2}{|c|}{$\mathrm{LC}=(\mathrm{LCH}+\mathrm{HSC}) * \mathrm{HO}$} \\
\hline \multicolumn{2}{|c|}{ Where:LCH $=(\mathrm{LCE})^{*}(\mathrm{NLCE})+(\mathrm{LCT}) *(\mathrm{NLCT})$} \\
\hline & $\mathrm{HO}=\mathrm{DA} / \mathrm{PROD}$ \\
\hline
\end{tabular}

The following formula will be used to calculate the labor cost (LC):

$\begin{array}{ll}\text { DA } & \Rightarrow \text { Area to be Decontaminated } \\ \text { HO } & \Rightarrow \text { Hours of Operation } \\ \text { HSC } & \Rightarrow \text { Site Specific Health and Safety Labor Cost } \\ \text { LC } & \Rightarrow \text { Labor Cost } \\ \text { LCE } & \Rightarrow \text { Labor Cost for an Equipment Operator } \\ \text { LCH } & \Rightarrow \text { Labor Cost per Hour } \\ \text { LCT } & \Rightarrow \text { Labor Cost for a Technician } \\ \text { NLCE } & \Rightarrow \text { Number of Equipment Operators } \\ \text { NLCT } & \Rightarrow \text { Number of Technicians } \\ \text { PROD } & \Rightarrow \text { Production Rate }\end{array}$

The following formula will be used to calculate the waste disposal cost.

$$
W D=W D C * W V^{*} D A
$$

DA $\quad \Rightarrow$ Area to be Decontaminated

WD $\quad \Rightarrow$ Waste Disposal Cost

WDC $\quad \Rightarrow$ Site Specific Waste Disposal Cost 
WV $\Rightarrow$ Waste Volume

\section{Assumptions for Cost Calculations:}

- Unit cost of implementing the technology will be calculated with units of $\$ /$ square foot.

- Utility costs including diesel fuel and electricity are not included.

- The same type and number of people used for the operation of the equipment are used to calculate the mobilization and demobilization costs.

- The costs to determine the location and amount of contamination and verification that the contamination is no longer there after the completion of the decontamination operations is not included in the cost calculations.

- Equipment decontamination costs are not included in the cost calculations.

- Project management costs (i.e. supervisors, etc.) are not included in the cost calculations.

- Overhead rates are not included in the cost calculations. 